\title{
CONVERGENCE OF REGIONAL ECONOMIC CYCLES IN TURKEY
}

\author{
Hasan Engin Duran \\ City and Regional Planning Department, Izmir Institute of Technology, Izmir, \\ Turkey
}

\begin{abstract}
Dissimilar economic fluctuations and asymmetric shocks across the regions of a country might create severe policy distortions that, under these circumstances, aggregate policy interventions (such as taxation and interest rates), are likely to be sub-optimal for at least a fraction of the regions. For instance, monetary policy can hardly satisfy the needs of all regions when some of the regions are experiencing a boom while others are in a recession phase. For these reasons, similarity of regional business cycles and their convergence are highly desirable from a policy viewpoint. The aim of this paper is, therefore, to provide empirical evidence and policy implications in that context. In particular, I analyze business cycle correlations across Turkish provinces and the tendency of these cycles to converge over the period of analysis between 1975-2000 and 2004-2008 (for Nomenclature of Territorial Units for Statistics [NUTS]-2 regions). I find that regional business cycle asymmetries have tended to decrease in recent decades. This result, although it seems to provide evidence in favor of rising correlations, shows that the convergence process is rather slow and there still exist asymmetries across the regional business cycles.
\end{abstract}

\section{Introduction}

Dissimilar economic fluctuations and asymmetric shocks across the regions of a country might create severe policy distortions that, under these circumstances, aggregate policy interventions (such as taxation and interest rates), are likely to be sub-optimal for at least a fraction of the regions (Mundel 1961; Frankel \& Rose 1998; Weyerstrass et al. 2011). For instance, monetary policy can hardly satisfy the needs of all regions when some of the regions are experiencing a boom while others are in a recession phase. For these reasons, similarity of regional business cycles and their convergence are highly desirable from a policy viewpoint.

With regard to the existing literature in this field, the majority of studies focus on the similarity of business cycles within the European Union. However, scholars are far from reaching a consensus. On the one hand, several authors argue that co-movements of the business cycles within Europe have tended to increase recently, particularly after the introduction of the European Exchange Rate Mechanism (Fatás 1997; Montoya \& De Haan 2008; Ferreira-Lopes \& Sequeira 2011). On the other hand, others adopt a pessimistic 
view and point to the presence of idiosyncratic shocks and the low degree of business cycle synchronization (Clark \& Van Wincoop 2001; Belke \& Heine 2006).

From a theoretical point of view, lack of synchronization is mostly explained by inadequate cross-border trade and financial linkages, dissimilarities in the industrial structure and labor market arrangements. Moreover, different responses of the regions to common shocks, such as unanticipated changes in interest rates, commodity prices and productivity shocks might contribute to the process of cyclical divergence (Carlino \& DeFina 1998; Imbs 2004; Selover et al. 2005).

In contrast to the European case, it has been widely accepted that US states have been characterized by highly similar economic fluctuations, and, therefore, the US is often regarded as a benchmark for the Eurozone as an optimal currency area (Carlino \& Sill 2001; Owyang et al. 2005).

Although the issues above have been thoroughly and heatedly discussed in regard to the Eurozone (i.e. Darvas \& Szapary 2008, Weyerstrass et al. 2011; Ferreira-Lopes \& Sequeira 2012 [for Swiss regions]) and the US (Carlino \& Sill 2001; Ferreira-Lopes \& Pina 2011), little attention has been devoted to developing countries (Calderon et al. 2007).

Turkey is one of the developing countries in which there are sizable differences across regions and provinces in the socio-economic and geographical structure, which makes Turkey an interesting place for study (Yildirim et al. 2009).

There is only one study in the literature, by Filiztekin (2004), regarding Turkey in the context of regional business cycles. There are other papers dealing with the business cycle of the Turkish economy at the aggregate level. One particular study was implemented by Alp et al. (2012), characterizing the stylized facts and main features of the national business cycle, such as its volatility, timing, and persistence.

Filiztekin (2004) analyzes the co-movements across the business cycles of Turkish regions from 1975 to $2000 .{ }^{1}$ He concludes that symmetries across regional cyclical movements are low during the 1980s, but higher during the 1990s. Moreover, he reports evidence in favor of the significant impact of regional differences in industrial specialization on the asymmetric evolution of business cycles.

It is important to emphasize that there are several differences between my study and Filiztekin's (2004). First, in addition to the analysis of synchronization during 1975-2000, I also provide evidence from a recent dataset which covers the period of 2004-2008 for Nomenclature of Territorial Units for Statistics (NUTS)-2 level regions.

Second, in addition to Filiztekin (2004), I analyze in detail the timing of the business cycle phases of provinces, explore the diffusion of recessions within the country, and also calculate precisely the idiosyncratic component of provincial business cycles.

Third, I measure the business cycles, not by using simple growth rates of regional economies (as in Filiztekin [2004]), but rather adopt various filtering techniques in order to estimate the deviation cycles of regions. De-trending techniques are, in general, more accurate than simple growth rates as the GDP might be growing below or above its potential, and simple growth rates do not capture these movements.

The aspects above constitute my contribution to the existing literature in this field. My set of research questions is summarized as follows:

\footnotetext{
${ }^{1}$ Filiztekin's study is written in Turkish, which is the only version of the article available. To the best of my knowledge, there appear to be no other papers written in English in this field.
} 
(i) What is the degree of business cycle synchronization (co-movement) across provinces in Turkey? Do recessions diffuse homogenously across the provinces? Do idiosyncratic components cover a large share of total variability in provincial business cycles?

(ii) Do province-level business cycles tend to converge over time? How about the level of synchronization recently? How can I explain, theoretically, the observed patterns?

What are the implied economic policies?

Data availability is my major concern in selecting the variable of interest, as well as the time period. The Turkish Statistical Institute does not publish any regional GDP data for the 20012004 period. It has published GDP data for 67 provinces from 1975 to 2000, and gross value added data for 27 NUTS-2 regions from 2004 to 2008. Therefore, I am bound to analyze these periods separately using different variables.

The organization of my paper is as follows: In Section 2.1 I analyze the synchronization across provincial business cycles, explore the diffusion of recessions within the country, and show the importance of idiosyncratic movements of provincial economies. Section 2.2 is devoted to understanding whether provincial business cycles tend to converge over time, and to providing evidence on synchronization from the most recent dataset (2004-2008) for NUTS-2 level regions. In Section 3, I conclude my study.

\section{Empirical Analysis}

\section{I. Analysis of Business Cycle Synchronization, 1975-2000}

Estimating the business cycles of provinces and the aggregate economy is the essential first step in my empirical analysis. A variety of methodologies have been employed in the literature in order to measure the economic cycles (Hodrick \& Prescott [hereafter referred to as HP] 1997; Baxter \& King [hereafter referred to as BK] 1999). Among others, I would like to employ two of the most commonly adopted methodologies (HP and BK) because of their simplicity and wide use in the literature.

In terms of provincial data, I employ per capita real gross regional product (at 1987 prices) for 67 provinces and the aggregate economy from 1975 to 2000. The dataset has been obtained from Karaca (2004) and Kasman and Turgutlu (2009), who constructed and used a dataset using resources from SPO and Turkstat. ${ }^{2}$

With regard to the choice of spatial units, it is worth noting that although new provinces emerged recently, I consider these provinces as belonging to the initial provinces, which results in 67 provinces in total.

The first filtering methodology that I use is that developed by HP (1997), which aims at estimating long-term trends of the economy and then calculating the deviations of the actual output from the trends. Therefore, the years in which the economy is growing faster (or slower) than its trend are referred to as expansion (or recession) periods. Specifically, the HP filter minimizes in trend $\left(\tau_{t}\right)$ the following expression:

$$
\min \sum_{t=1}^{T}\left(y_{t}-\tau_{t}\right)^{2}+\lambda \sum_{t=2}^{T-1}\left[\left(\tau_{t+1}-\tau_{t}\right)-\left(\tau_{t}-\tau_{t-1}\right)\right]^{2}
$$

\footnotetext{
${ }^{2}$ I am heartily grateful to Orhan Karaca, Adnan Kasman, and Evrim Turgutlu for sharing their dataset with me. SPO, State Planning Organization; Turkstat, Turkish Statistical Institute.
} 
$y$ is the actual output and $\lambda$ is a penalty parameter which captures the smoothness of the trend, $\tau_{t}$. The filter produces smoother estimates of $\tau_{t}$ as $\lambda$ increases. For annual data, I set $\lambda=100$, as recommended by HP (1997). Having estimated $\tau_{t}$, I simply calculate the deviations of the output from its trend.

An alternative way of estimating the business cycles is to employ the Band-Pass filtering developed by BK (1999). Specifically, it removes low- and high-frequency movements in the data and directly extracts the cyclical fluctuations, with their periodicity in a certain range. Specifically, I use 1.5 and 8 years for low $(\mathrm{L})$ and high $(\mathrm{H})$ frequency parameters in BK filtering. Moreover, the number of lags adopted in BK filtering is selected on a basis of Akaike (AIC) criterion for each province.

The resulting estimation of the business cycles for the Turkish economy is depicted in Figure 1, from which it can be immediately noted that the two measures seem to be consistent with each other, as they exhibit highly synchronous oscillations.

\section{I.I. Business cycle co-movements across provinces}

In order to analyze the degree of business cycle co-movement among provinces, I calculate the Pearson correlation coefficient between the business cycles of each province and the aggregate economy. Because the aggregate economy is interpreted as the weighted average of all provinces, pairwise correlations between provinces and the aggregate economy are useful to understand the level of synchronization within the country. The geographical distribution of these correlations, as well as their cross-sectional mean and standard deviation, are presented in Figure 2 and Table 1.

At a glance, in Figure 2 I observe that provinces located in the Black Sea region and eastern Anatolia are characterized by business cycles that are less correlated with the aggregate economy, and, therefore, seem to be less tied to national market forces, most probably as a result

Figure 1. Aggregate Business Cycles in Turkey, 1975-2000

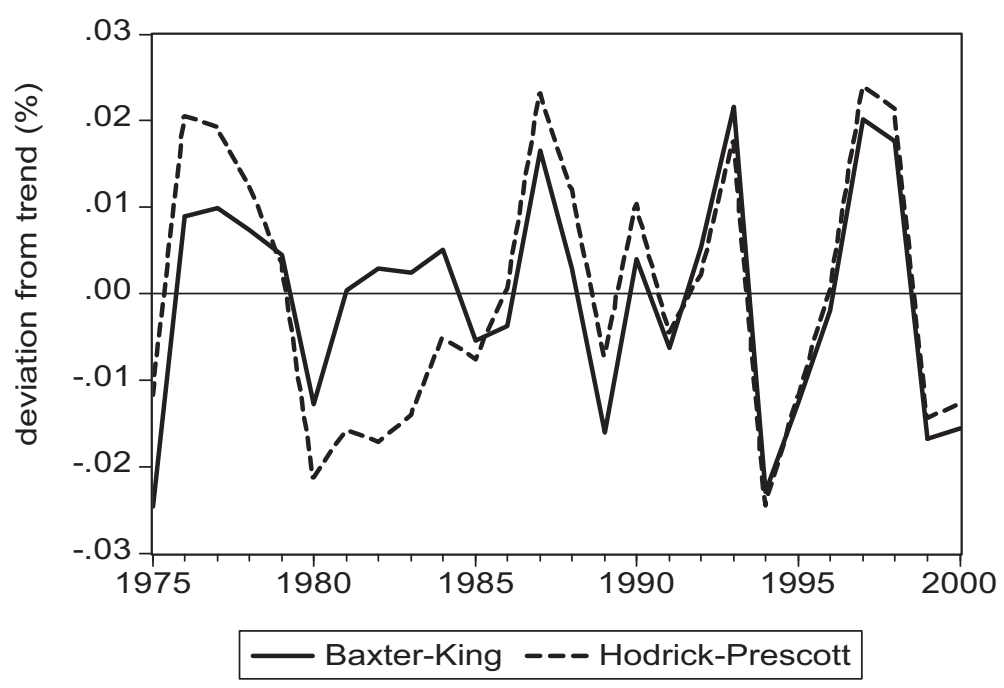

(c) The Applied Regional Science Conference (ARSC)/Wiley Publishing Asia Pty Ltd 2013 
Figure 2. Business cycle correlation between provinces and the aggregate economy. (a) Hodrick-Prescott filtering used. (b) Baxter-King filtering used

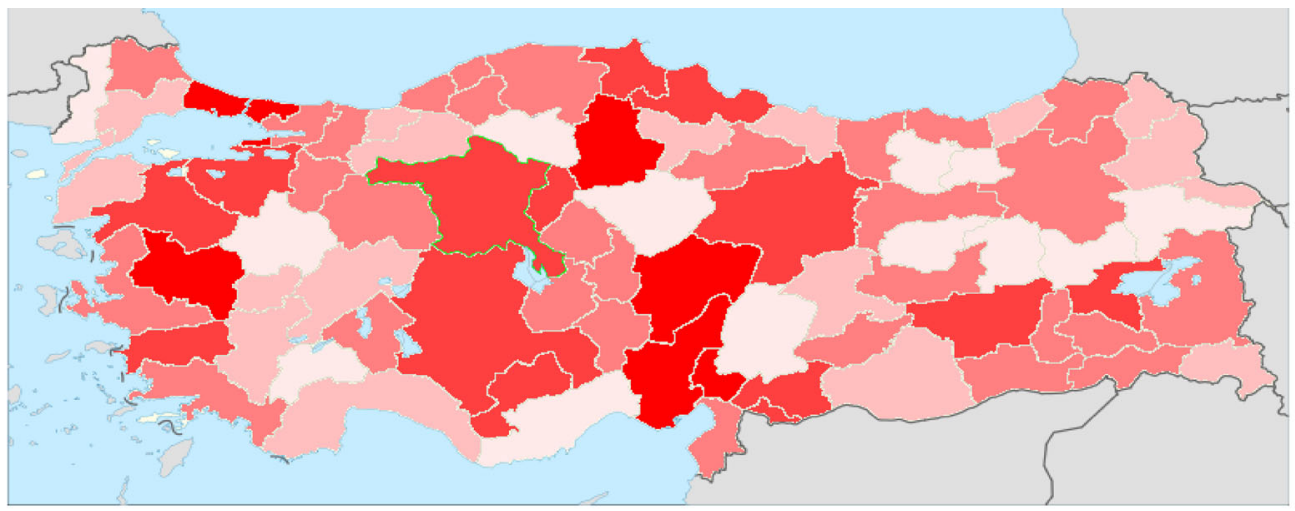

(a)

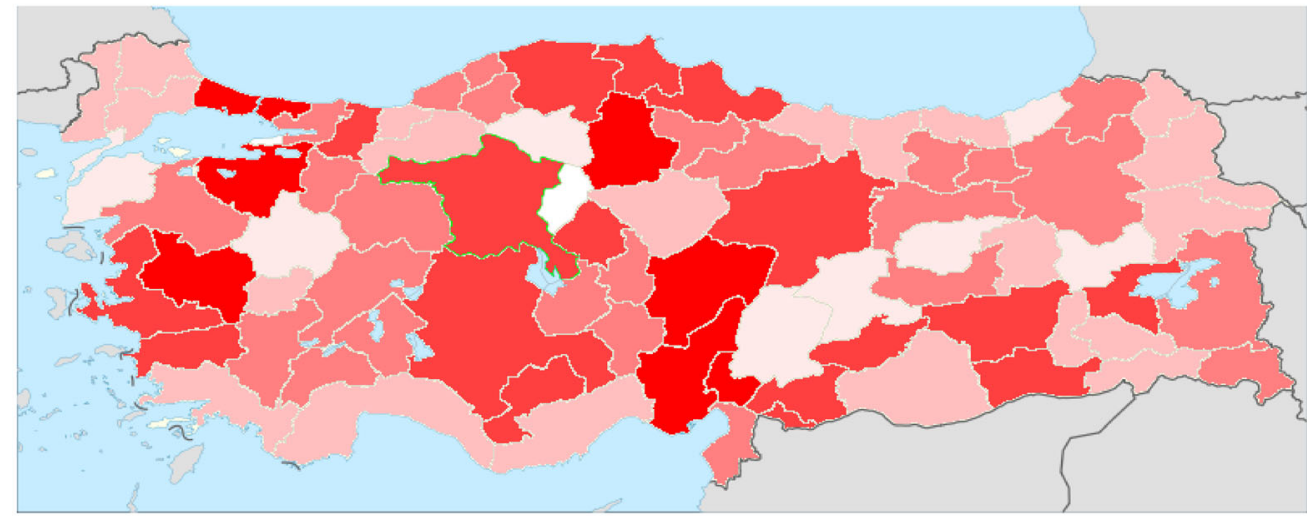

(b)

\begin{tabular}{|c|c|}
\hline$>0.80$ & \\
\hline $0.60-0.80$ & \\
\hline $0.40-0.60$ & \\
\hline $0.20-0.40$ & \\
\hline$<0.20$ & \\
\hline
\end{tabular}

of the presence of idiosyncratic shocks and an arbitrary industrial structure. In contrast, provinces in the Marmara region, and middle and western Anatolia, exhibit high correlation with the aggregate economy. In detail, provinces that have business cycles that are the most correlated with the aggregate economy are: Kayseri (0.86 correlation), Adana (0.85), and Istanbul (0.85) for HP cycles, and Manisa (0.90), Istanbul (0.89), and Kayseri (0.84) for BK cycles. Conversely, the ones with the lowest correlation are: Kahramanmaraş ( -0.09$)$, Yozgat $(-0.10)$, and Içel $(-0.12)$ for HP cycles, and Kütahya (0.02), Çanakkale (0.02), and Kahramanmaraş $(-0.05)$ for BK cycles. The cross-sectional average of the correlations is 0.43 for HP and 0.47 for BK filtering. 
Table 1. Business cycle correlation between provinces and aggregate economy

\begin{tabular}{|c|c|c|c|c|c|}
\hline Provinces & HP & $\mathrm{BK}$ & Provinces & HP & $\mathrm{BK}$ \\
\hline Adana & 0.85 & 0.80 & Kahramanmaraş & -0.09 & -0.05 \\
\hline Adiyaman & 0.44 & 0.64 & Kars & 0.26 & 0.23 \\
\hline Afyon & 0.36 & 0.43 & Kastamonu & 0.46 & 0.73 \\
\hline 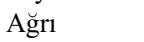 & 0.10 & 0.25 & Kayseri & 0.86 & 0.84 \\
\hline Amasya & 0.37 & 0.53 & Kırklareli & 0.53 & 0.35 \\
\hline Ankara & 0.62 & 0.61 & Kurşehir & 0.49 & 0.64 \\
\hline Antalya & 0.31 & 0.25 & Kocaeli & 0.41 & 0.53 \\
\hline Artvin & 0.43 & 0.44 & Konya & 0.73 & 0.78 \\
\hline Aydın & 0.68 & 0.60 & Kütahya & -0.01 & 0.02 \\
\hline Balıkesir & 0.61 & 0.40 & Malatya & 0.29 & 0.03 \\
\hline Bilecik & 0.50 & 0.47 & Manisa & 0.85 & 0.90 \\
\hline Bingöl & 0.12 & 0.39 & Mardin & 0.57 & 0.60 \\
\hline Bitlis & 0.69 & 0.73 & Muğla & 0.52 & 0.37 \\
\hline Bolu & 0.32 & 0.36 & Muş & 0.13 & 0.19 \\
\hline Burdur & 0.17 & 0.43 & Nevşehir & 0.55 & 0.41 \\
\hline Bursa & 0.78 & 0.82 & Nïğgde & 0.51 & 0.58 \\
\hline Çanakkale & 0.22 & 0.02 & Ordu & 0.25 & 0.25 \\
\hline Çankırı & 0.08 & 0.14 & Rize & 0.37 & 0.13 \\
\hline Çorum & 0.84 & 0.83 & Sakarya & 0.55 & 0.61 \\
\hline Denizli & 0.39 & 0.53 & Samsun & 0.63 & 0.71 \\
\hline Diyarbakır & 0.65 & 0.62 & Siirt & 0.42 & 0.32 \\
\hline Edirne & 0.05 & 0.31 & Sinop & 0.69 & 0.78 \\
\hline Elazı ̆ & 0.48 & 0.58 & Sivas & 0.65 & 0.67 \\
\hline Erzincan & 0.48 & 0.42 & Şanlıurfa & 0.24 & 0.34 \\
\hline Erzurum & 0.49 & 0.46 & Tekirdağ & 0.24 & 0.38 \\
\hline Eskişehir & 0.57 & 0.58 & Tokat & 0.40 & 0.56 \\
\hline Gaziantep & 0.72 & 0.71 & Trabzon & 0.47 & 0.35 \\
\hline Giresun & 0.54 & 0.39 & Tunceli & 0.01 & 0.05 \\
\hline Gümüşhane & 0.16 & 0.44 & Uşak & 0.38 & 0.25 \\
\hline Hakkari & 0.29 & 0.45 & Van & 0.51 & 0.59 \\
\hline Hatay & 0.50 & 0.50 & Yozgat & -0.10 & 0.32 \\
\hline Isparta & 0.46 & 0.56 & Zonguldak & 0.48 & 0.56 \\
\hline İçel & -0.12 & 0.27 & & & \\
\hline İstanbul & 0.85 & 0.89 & Mean & 0.43 & 0.47 \\
\hline İzmir & 0.46 & 0.63 & Weighted Mean & 0.51 & 0.55 \\
\hline
\end{tabular}

BK, Baxter-King; HP, Hodrick-Prescott.

It is well known that there are important differences in the economic sizes of provinces. Therefore, the unweighted average of correlations might be spurious for the implied policies. Thus, I also need to calculate the weighted average of correlations using populations of provinces relative to the aggregate population. The resulting calculations are presented in the last row of Table 1, where the cross-sectional weighted average of the correlations now becomes 0.51 for HP and 0.55 for BK filterings. Although these values indicate higher synchronization compared to the initial (unweighted) case, the average degree of synchronization is still far below 1 (perfect correlation), and one may consequently argue that there are considerably large cyclical asymmetries across the provinces.

Also, to support these results from a methodological point of view, I present the empirical distributions of the correlations in Figure 3 using kernel density estimations. I observe that 
Figure 3. Kernel density estimation: distribution of business cycle correlations. (a) Hodrick-Prescott. (b) Baxter-King

(a)

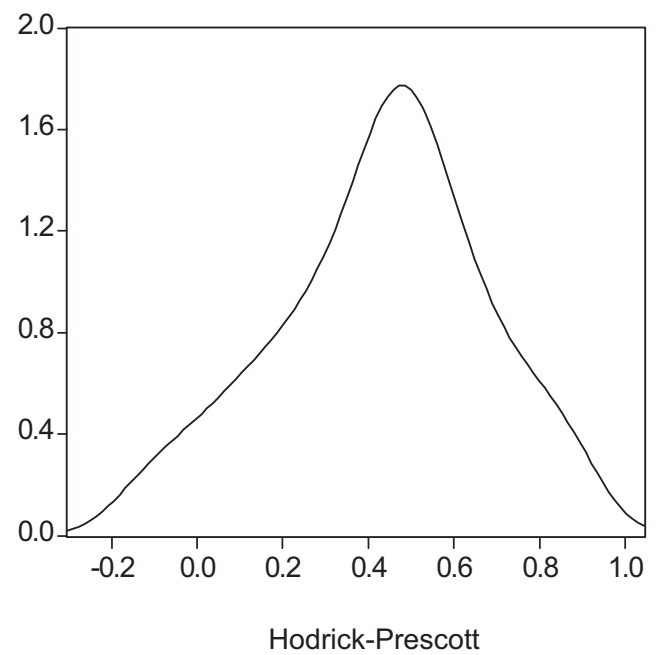

(b)

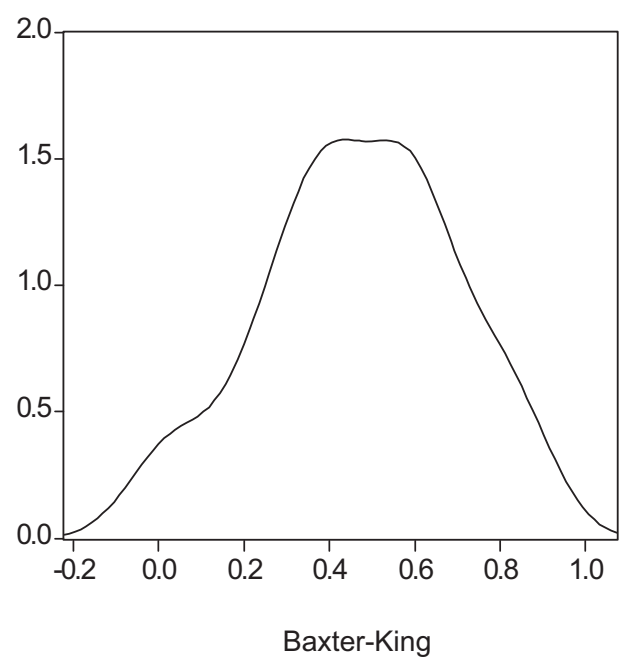

probability mass is mostly concentrated around $0.40-0.50$ in all business cycle types with a reasonably dispersed distribution (expect for the HP filtering). In total, these results confirm once more the presence of low synchronization and sizable asymmetries across cyclical fluctuations of the provinces.

One of the most plausible explanations of the observed asymmetries is the dissimilarity in the industrial structure of the provinces. As anticipated, if provinces differ largely in their industrial specialization, they will react differently to the common and sector-specific shocks and, therefore, experience dispersed cyclical movements (Krugman 1991; Kalemli-Özcan et al. 2001; Selover et al. 2005). In my case, for instance, provinces with a high share of agricultural employment in east and northern Anatolia are likely to be less influenced by the common shocks (Filiztekin 2004). In contrast, those provinces which specialize in manufacturing, particularly in durable and intermediate goods, are likely to respond more promptly to unanticipated economic circumstances, such as changes in prices, interest rates, and technological developments. Consequently, it is natural to observe distinct stochastic developments across the provinces. To support these interpretations, I find it useful to present the sectoral specialization of provinces in Table 2.

Two important points appear to emerge from Table 2. First, there is a substantial heterogeneity among sectoral specialization of provinces that possibly plays a key role in the emergence of asymmetric business cycles. This heterogeneity is present in almost all sectors, but more acute in industrial production (the cross-sectional standard deviations of sectoral shares are summarized in the last row). Second, western Anatolian provinces tend to specialize more in service, trade, and industry, while eastern provinces concentrate mostly on agriculture, which provides a further support for differential business cycles and the significance of eastwest dualism. 
Table 2. Share of sectors in gross domestic product (\%), 1987 values

\begin{tabular}{|c|c|c|c|c|c|c|c|c|c|}
\hline Provinces & Agriculture & Industry & Trade & Services & Provinces & Agriculture & Industry & Trade & Services \\
\hline Adana & 19.3 & 28.3 & 17.3 & 35.1 & Kars & 50.8 & 5.2 & 8.4 & 35.6 \\
\hline Adıyaman & 37.4 & 21.9 & 10 & 30.7 & Kastamonu & 43.4 & 7.9 & 7.2 & 41.5 \\
\hline Afyon & 33.4 & 14.5 & 14.6 & 37.5 & Kayseri & 14.6 & 17.1 & 28.6 & 39.7 \\
\hline Ağr1 & 42.5 & 4.7 & 11.1 & 41.7 & Kırklareli & 19.6 & 38.6 & 10.8 & 31.0 \\
\hline Amasya & 36.7 & 10.7 & 12.8 & 39.8 & Kurşehir & 37.6 & 8.2 & 13.8 & 40.4 \\
\hline Ankara & 6.9 & 15 & 23.3 & 54.8 & Kocaeli & 2.4 & 57.8 & 9.7 & 30.1 \\
\hline Antalya & 27.7 & 10 & 24.4 & 37.9 & Konya & 35.2 & 17.3 & 14.7 & 32.8 \\
\hline Artvin & 27.5 & 28.5 & 9.6 & 34.4 & Kütahya & 16.2 & 49.3 & 8.2 & 26.3 \\
\hline Aydın & 35.7 & 10.9 & 24.5 & 28.9 & Malatya & 22 & 26.4 & 18 & 33.6 \\
\hline Balıkesir & 27 & 22.5 & 12.5 & 38.0 & Manisa & 36.6 & 23.5 & 17 & 22.9 \\
\hline Bilecik & 21.3 & 45.3 & 5.2 & 28.2 & K. Maras & 29.3 & 23.2 & 17.5 & 30.0 \\
\hline Bingöl & 48.2 & 4 & 5.9 & 41.9 & Mardin & 39.6 & 7.9 & 14.8 & 37.7 \\
\hline Bitlis & 36.1 & 8.9 & 7.9 & 47.1 & Muğla & 25.6 & 25.9 & 23.3 & 25.2 \\
\hline Bolu & 30.4 & 21.1 & 14 & 34.5 & Muş & 49.7 & 4.3 & 4.8 & 41.2 \\
\hline Burdur & 39.2 & 7.3 & 13 & 40.5 & Nevşsehir & 57.4 & 4.2 & 9.9 & 28.5 \\
\hline Bursa & 16.5 & 33.4 & 18.2 & 31.9 & Niğde & 41.5 & 12 & 10.4 & 36.1 \\
\hline Çanakkale & 35.4 & 23.6 & 10.4 & 30.6 & Ordu & 37.4 & 10.2 & 16 & 36.4 \\
\hline Çankırı & 46.2 & 4.6 & 10.4 & 38.8 & Rize & 30.4 & 21.8 & 15.6 & 32.2 \\
\hline Çorum & 28.8 & 9.4 & 32.4 & 29.4 & Sakarya & 29.4 & 16 & 18.2 & 36.4 \\
\hline Denizli & 34.1 & 14 & 21.2 & 30.7 & Samsun & 29.6 & 16.2 & 24.3 & 29.9 \\
\hline Diyarbakır & 20.1 & 29.4 & 18.3 & 32.2 & Siirt & 22.9 & 43.5 & 2.5 & 31.1 \\
\hline Edirne & 40.5 & 14.2 & 13.6 & 31.7 & Sinop & 38.9 & 10.9 & 10.4 & 39.8 \\
\hline Elazı $\breve{g}$ & 15.5 & 40.1 & 11.5 & 32.9 & Sivas & 27.3 & 10.7 & 16.2 & 45.8 \\
\hline Erzincan & 35.9 & 13.2 & 18.7 & 32.2 & Tekirdağ & 25 & 29.9 & 10.9 & 34.2 \\
\hline Erzurum & 23 & 11 & 18 & 48.0 & Tokat & 28.4 & 25.2 & 10.5 & 35.9 \\
\hline Eskişehir & 14.7 & 24.3 & 26.1 & 34.9 & Trabzon & 41.8 & 3.5 & 9.3 & 45.4 \\
\hline Gaziantep & 18.7 & 18.7 & 27.8 & 34.8 & Tunceli & 26.4 & 18.3 & 18 & 37.3 \\
\hline Giresun & 36.4 & 13.3 & 12 & 38.3 & Şanlıurfa & 54.8 & 1.1 & 6 & 38.1 \\
\hline Gümüşhane & 37.5 & 4.3 & 10.1 & 48.1 & Uşak & 38.7 & 10.3 & 20.4 & 30.6 \\
\hline Hakkari & 46.4 & 1.3 & 4.3 & 48.0 & Van & 22.7 & 6.2 & 13.4 & 57.7 \\
\hline Hatay & 19.8 & 18.9 & 25.4 & 35.9 & Yozgat & 45.6 & 12.4 & 8.8 & 33.2 \\
\hline Isparta & 29.9 & 20.4 & 12.2 & 37.5 & Zonguldak & 13.7 & 45.5 & 8.6 & 32.2 \\
\hline İçel & 22 & 29.9 & 16.5 & 31.6 & & & & & \\
\hline İstanbul & 1.2 & 33.4 & 28.1 & 37.3 & Mean & 30.4 & 18.7 & 14.8 & 36.2 \\
\hline İzmir & 10.4 & 29.9 & 22.1 & 37.6 & SD & 12.1 & 12.7 & 6.7 & 6.6 \\
\hline
\end{tabular}

Source: Turkish Statistical Institute (TURKSTAT). SD, standard deviation.

\subsubsection{Diffusion of recessions}

Another way of investigating the synchronicity of regional business cycles is through the analysis that explores the timing of business cycles and diffusion of phases within the country. The Turkish economy experienced several recessions during the 1980s and 1990s. In Figure 1, I clearly observe the times of economic downturns and expansions that depict the business cycle of the Turkish economy. Some of these recessions lasted only one year and some of them were more prolonged, lasting up to a few years.

Regarding the way I determine the timing of recessions and expansions, the years in which the national economy grows faster than its trend are defined as expansions and, by contrast, periods during which the economy grows slower than its trend are referred to as downturns. 
To illustrate how recessions are distributed within the country, I map the provinces that experience expansions and downturns in Figure 4 at the most severe year of the national recession, that is, the year with the lowest national economic growth (relative to trend) during the recession.

Provinces that grow below their trend growth are labeled in gray, which represent downturns. I use both HP and BK filtering in estimating the trend of national and provincial economies.

Figure 4. Diffusion of Recessions within the country. (a) Baxter-King filtering used. (b) Hodrick-Prescott filtering used
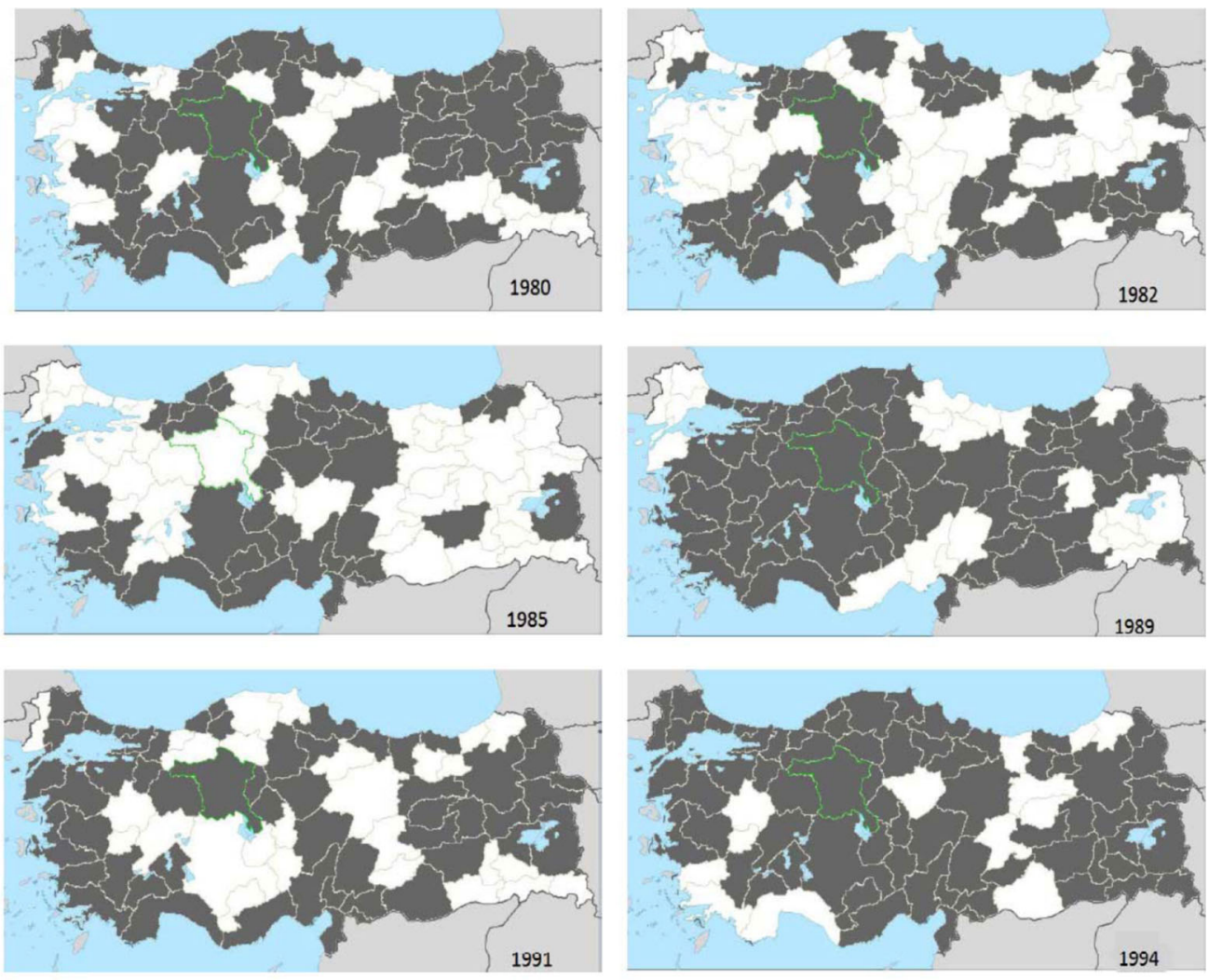

(a)

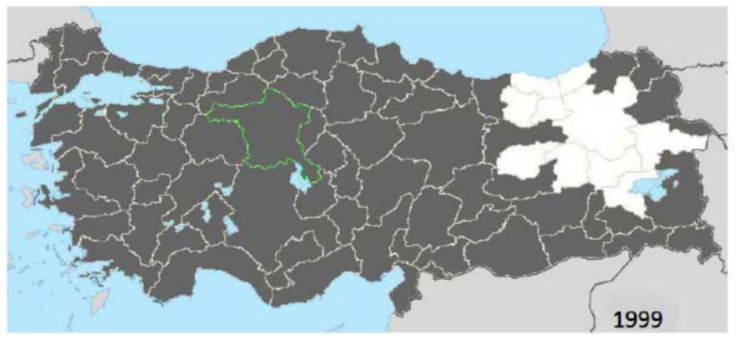


Figure 4. Continued
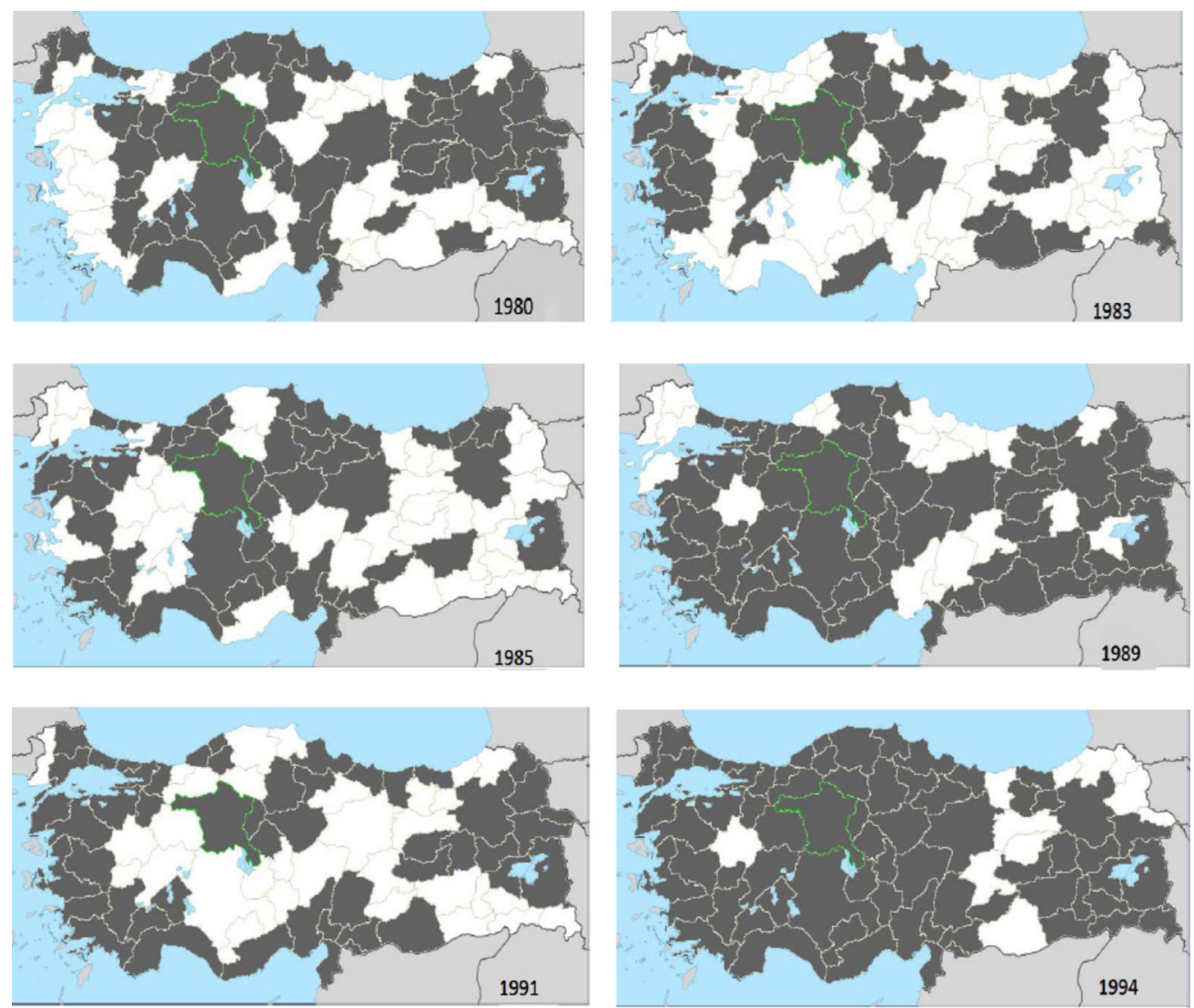

(b)

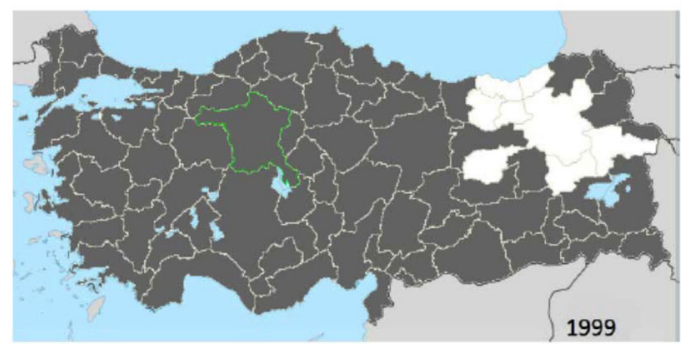

At a glance, I observe that recessions are weakly diffused during the 1980s (such as in 1980, 1982-1983, 1985), as many provinces remain in an expansion phase when the aggregate economy is already in recession. However, from the mid-1990s onwards I observe a more homogenous and strong diffusion of recessions within the country, particularly in 1994 and 1999. In total, these results point to the increasing co-movement and synchronization among provincial business cycles while idiosyncratic movements seem to fade out. These results hold true for both HP and BK types of business cycles. 


\section{I.3. Idiosyncratic components of provincial business cycles}

Idiosyncratic movement of provincial economies is an important indicator that shows the extent to which provinces are untied to national market forces. In other words, a relatively higher idiosyncratic component implies higher business cycle asymmetry between provinces and the national economy. To shed light on this issue, I follow Ferreira-Lopes and Sequeira (2011) to precisely calculate the variability in idiosyncratic movements of provinces relative to total variability in their business cycles. This task has been achieved in two steps:

First, I calculate the idiosyncratic component of each provincial business cycle by using the following formula:

$$
P c y c_{t}=\delta+P c y c_{t-1}+P c y c_{t-2}+N c y c_{t}+N c y c_{t-1}+N c y c_{t-2}+\gamma
$$

Pcyc and Ncyc denote the provincial and national business cycles, respectively. I use up to twoyear time lags, as in Ferreira-Lopes and Sequeira (2011). Residual terms represent the idiosyncratic component of the provincial business cycle.

As a second step, I calculate the variability in idiosyncratic movements relative to the total variability in business cycles of provinces using the standard deviation as a measure of variability; $\sigma(\gamma) / \sigma(P c y c)$ where $\sigma$ denotes the standard deviation. The resulting estimations are summarized in Table 3.

It can be immediately noted that idiosyncratic variability covers an important share of total variability. Such as, on average, $74 \%$ (HP) or $70 \%$ (BK) of the business cycle variability of a province is a result of idiosyncratic movements. These values are far above the values calculated in Ferreira-Lopes and Sequeira (2011) for German Länder, which range between $21 \%$ and $46 \%$. Therefore, my analysis suggests that business cycle asymmetries and idiosyncratic movements in Turkey are very important and one should consider the severity of this fact for the possible policy distortions.

\subsection{Convergence of Business Cycles}

The tendency of province-level business cycles to converge is also crucial from a policy standpoint. As mentioned earlier, aggregate policy interventions, such as changes in interest rates, might create sizable distortions in cases where regions within a country experience different cycle phases. However, the distortions are likely to decrease if the business cycles of provinces tend to become more similar over time. The present section is devoted to analyzing the convergence patterns across the business cycles of provinces. In order to do so, using HP (1997) and BK's (1999) de-trended business cycles, I adopt the criterion for cyclical convergence put forward by Weyerstrass et al. (2011). They state that if all regions within a country tend to have business cycles perfectly correlated with the aggregate economy, one may speak of a cycle convergence. In other words, the cross-sectional average of the correlations between provinces and the aggregate economy should approach 1, while the cross-sectional variance of these correlations should approach 0 .

To implement such a convergence analysis, I adopt three types of methodologies. First, I chart the evolution of business cycle correlations between provinces and the aggregate economy, using rolling window time intervals of six years, rather than the entire period. Second, I employ a more comprehensive approach (conditional kernel density estimations) in order to directly observe the evolution of the distributions of business cycle correlations between 
Table 3. Variability of the idiosyncratic component/total variability of the business cycle

\begin{tabular}{|c|c|c|c|c|c|}
\hline Provinces & $\mathrm{BK}$ & HP & Provinces & $\mathrm{BK}$ & $\mathrm{HP}$ \\
\hline Adana & 0.494 & 0.394 & İzmir & 0.606 & 0.754 \\
\hline Adiyaman & 0.710 & 0.633 & Kars & 0.948 & 0.939 \\
\hline Afyon & 0.690 & 0.773 & Kastamonu & 0.534 & 0.673 \\
\hline A ̆ğn1 & 0.758 & 0.960 & Kayseri & 0.423 & 0.457 \\
\hline Amasya & 0.754 & 0.923 & Kırklareli & 0.740 & 0.674 \\
\hline Ankara & 0.686 & 0.653 & Kırşehir & 0.715 & 0.762 \\
\hline Antalya & 0.787 & 0.743 & Kocaeli & 0.585 & 0.755 \\
\hline Artvin & 0.878 & 0.763 & Konya & 0.431 & 0.598 \\
\hline Aydin & 0.835 & 0.744 & Kütahya & 0.826 & 0.895 \\
\hline Balıkesir & 0.787 & 0.716 & Malatya & 0.833 & 0.921 \\
\hline Bilecik & 0.738 & 0.762 & Manisa & 0.408 & 0.460 \\
\hline Bingöl & 0.639 & 0.866 & Kahramanmaraş & 0.814 & 0.874 \\
\hline Bitlis & 0.600 & 0.687 & Mardin & 0.537 & 0.577 \\
\hline Bolu & 0.800 & 0.750 & Muğla & 0.789 & 0.825 \\
\hline Burdur & 0.770 & 0.806 & Muş & 0.927 & 0.981 \\
\hline Bursa & 0.513 & 0.482 & Nevşehir & 0.833 & 0.723 \\
\hline Çanakkale & 0.891 & 0.964 & Niğğde & 0.763 & 0.824 \\
\hline Çankırı & 0.956 & 0.960 & Ordu & 0.708 & 0.856 \\
\hline Çorum & 0.495 & 0.482 & Rize & 0.880 & 0.852 \\
\hline Denizli & 0.782 & 0.898 & Sakarya & 0.648 & 0.777 \\
\hline Diyarbakır & 0.632 & 0.594 & Samsun & 0.613 & 0.697 \\
\hline Edirne & 0.895 & 0.861 & Siirt & 0.867 & 0.850 \\
\hline Elazı̆ ğ & 0.635 & 0.828 & Sinop & 0.351 & 0.569 \\
\hline Erzincan & 0.486 & 0.561 & Sivas & 0.536 & 0.657 \\
\hline Erzurum & 0.820 & 0.740 & Tekirdağ & 0.656 & 0.754 \\
\hline Eskişehir & 0.714 & 0.751 & Tokat & 0.576 & 0.726 \\
\hline Gaziantep & 0.544 & 0.557 & Trabzon & 0.745 & 0.772 \\
\hline Giresun & 0.637 & 0.610 & Tunceli & 0.774 & 0.886 \\
\hline Gümüşhane & 0.745 & 0.748 & Şanlıurfa & 0.659 & 0.796 \\
\hline Hakkari & 0.796 & 0.897 & Uşak & 0.794 & 0.725 \\
\hline Hatay & 0.690 & 0.719 & Van & 0.772 & 0.694 \\
\hline Isparta & 0.703 & 0.780 & Yozgat & 0.850 & 0.778 \\
\hline İçel & 0.818 & 0.788 & Zonguldak & 0.759 & 0.689 \\
\hline İstanbul & 0.393 & 0.437 & Mean & 0.701 & 0.740 \\
\hline
\end{tabular}

BK, Baxter-King; HP, Hodrick-Prescott.

provinces and the aggregate economy. Third, I evaluate bilateral (pairwise) business cycle correlations among provinces over the sub-periods.

\subsection{Rolling window business cycle correlations}

As a first methodology, I present the evolution of cross-sectional average of business cycle correlations between provinces and the aggregate economy in Figure 5, which helps in observing the evolution of the average degree of synchronization within the country. The time horizon displays the end points of the rolling window time intervals, such that 1980 actually represents the period from 1975-1980.

At a glance in Figure 5a, an increasing synchronization over time is clearly observable. This pattern is consistent across different types of business cycles. While during the 1975-1980 
Figure 5. Average of rolling window business cycle correlations between provinces and the aggregate economy. (a) Unweighted values. (b) Population weighted values

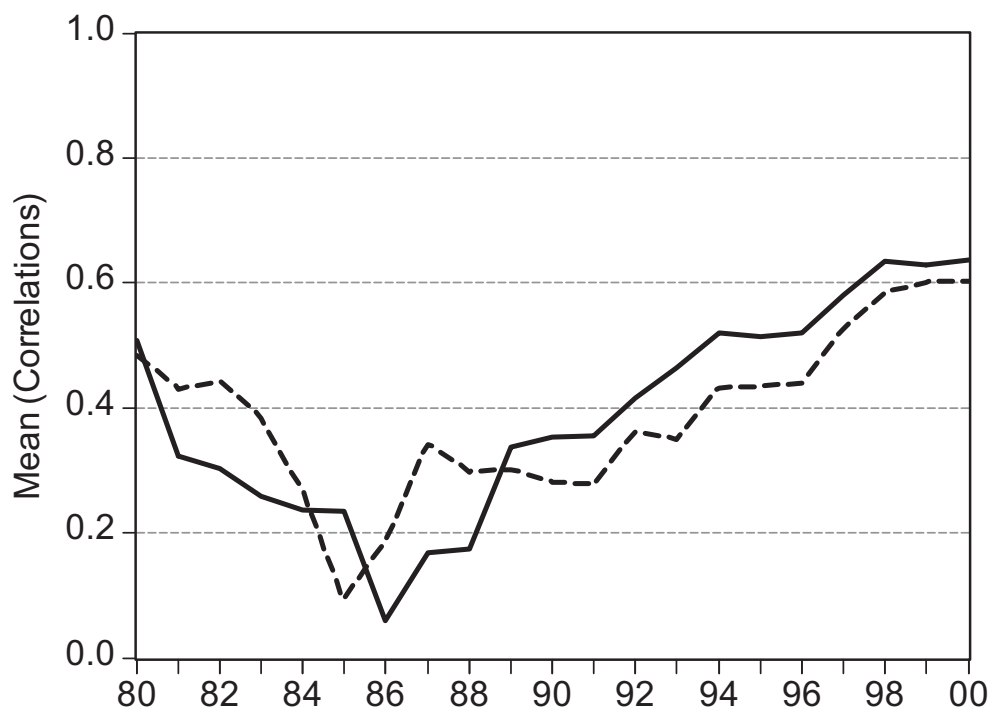

(a)

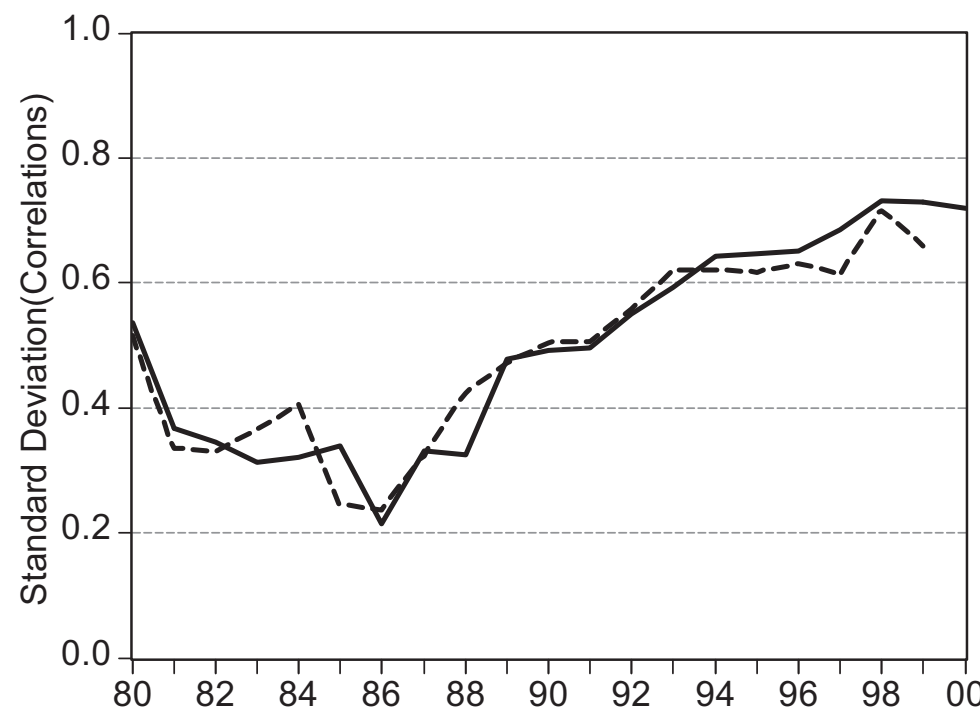

(b)

$$
\text { BK --- HP }
$$


period a province, on average, has a business cycle correlation of 0.50 with the aggregate economy, this value reduces to $0.10-0.20$ for the $1981-1986$ period and steadily increases and reaches levels of 0.6-0.7 in 1995-2000. With regard to the second moment of the correlations, Figure 6a displays the cross-sectional standard deviation. The dispersion of the correlations tends to reduce over time. Initially, for the period of 1975-1980, the standard deviation is between 0.40 and 0.50 , which increases to the level of 0.60 in the period of 1982-1987 and reduces to below 0.40 during the late $1990 \mathrm{~s}$.

The values in Figures 5a and 6a, however, are in an unweighted form. As anticipated, unweighted values might distort the results as provinces differ largely in their economic sizes. To address this issue, I also present the same graphs using population-weighted values. As an outcome, rising synchronization and declining dispersion of correlations have been observed once more, as Figures $5 \mathrm{~b}$ and $6 \mathrm{~b}$ exhibit similar patterns to Figures $5 \mathrm{a}$ and $6 \mathrm{a}$.

In total, I observe a tendency of provincial business cycles to converge, as the correlations tend to increase over time with a lower cross-sectional dispersion. However, this process seems to be rather slow and cycle asymmetries are still present.

\subsubsection{Conditional kernel density estimation}

As a second approach, I estimate the conditional kernel density estimations of the correlations presented in Figures 5 and 6. Conditional density estimation is a tool that specifically allows me to observe the evolution of the distribution of correlations, the concentration of probability mass, and the main features of the distribution, such as its first and second moment. ${ }^{3}$

In Figure 7, the estimations tell more or less the same story for each business cycle type. In line with the first approach, the probability mass tends to accumulate around higher values after the mid-80s, which indicates the increasing correlations between provinces and the aggregate economy. Furthermore, the distributions experience a transformation in their shape, switching from bi-modal to uni-modal and a more homogenous form. Overall, an increasing pattern of synchronization within the country is once more confirmed using an alternative approach.

The trade and financial liberalization process in Turkey in recent decades most probably motivates economic explanations of the observed patterns. As is well known, after 1980, macroeconomic policies in Turkey underwent an important transformation; in particular, from an approach based on the import substitution to an economic model that favors economic and financial liberalization, such as increasing trade ties and factor flows in the international context, and also among the regions of the country (Gezici \& Hewings 2004). Rising synchronization, therefore, might be seen as a consequence of two main components of this integration process.

The first component is the intense cross-border trade linkages across provinces. Consistent with the existing literature in this field, strong trade ties among the regions might lead to the spillover of business cycles caused by input-output relations, which, in turn, foster the convergence of economic cycles across spatial units (Frankel \& Rose 1998; Baxter \& Kouparitsas 2005). In other words, declining asymmetries in the cycles serve as anecdotal evidence in support of the conventional argument that trade openness creates strong linkages across regional economies that share similar economic shocks (Lee 2005).

\footnotetext{
${ }^{3}$ Conditional kernel density estimations have been implemented using the "hdrcde" $\mathrm{R} 2.13$ package. The main parameters: degree of local polynomial is 0 and link function is specified as "identity."
} 
Figure 6. Cross sectional standard deviation of business cycle correlations between provinces and the aggregate economy. (a) Unweighted values. (b) Population weighted values
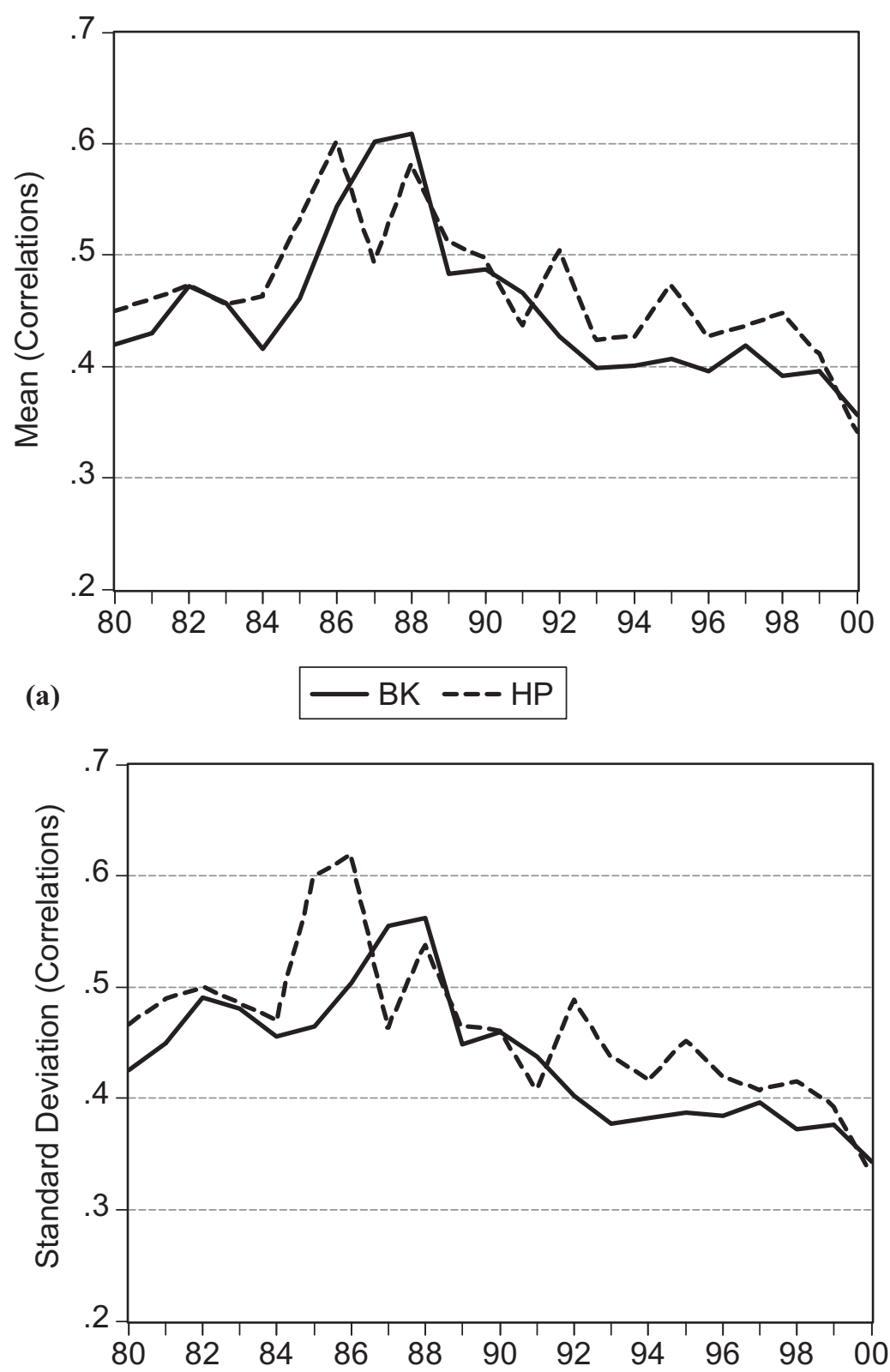

(b)

$$
\longrightarrow B K---H P
$$


Figure 7. Convergence of provincial business, conditional kernel density estimation. (a) Hodrick-Prescott filtering used. (b) Baxter-King filtering used

(a)
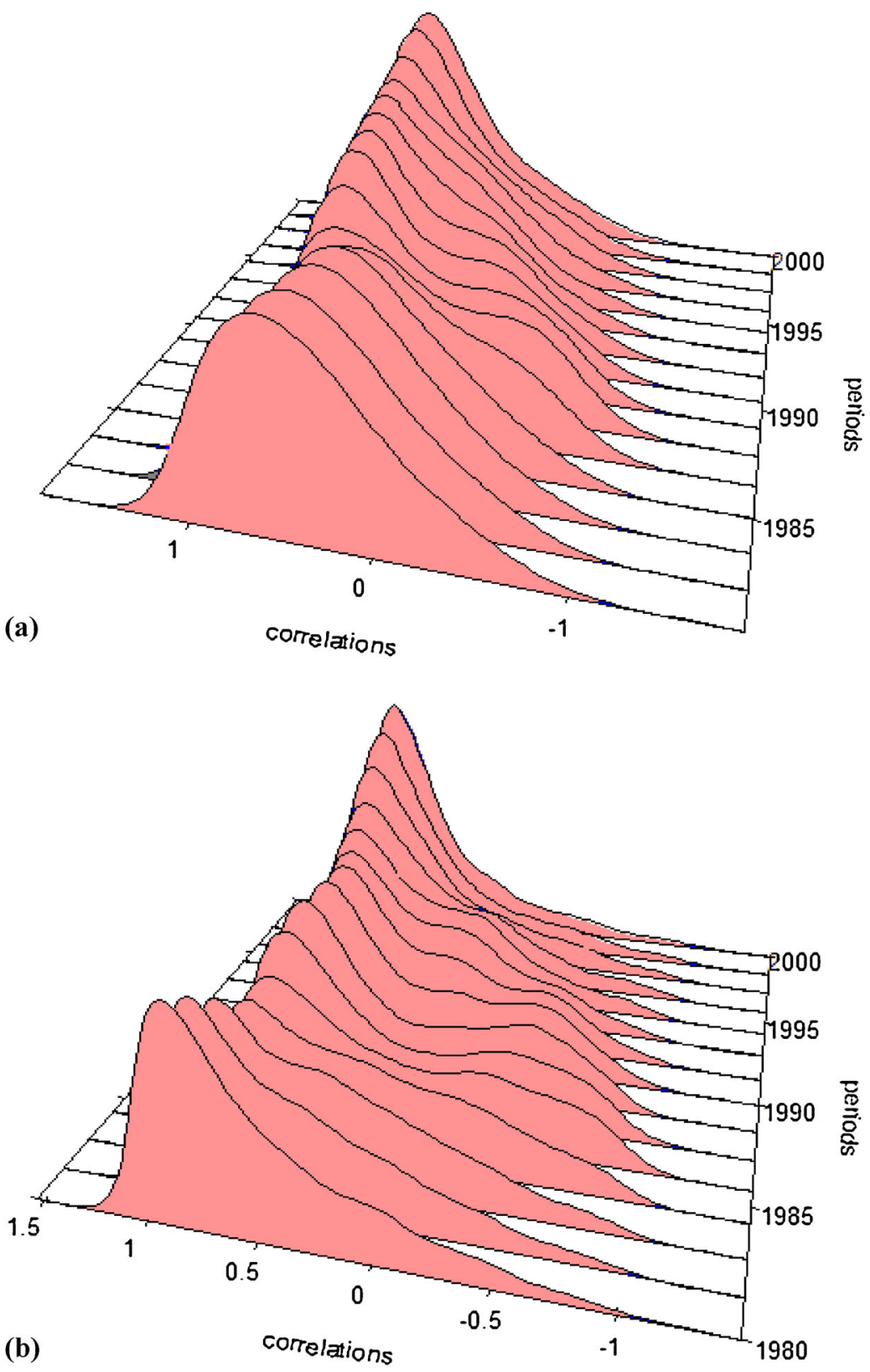

(c) The Applied Regional Science Conference (ARSC)/Wiley Publishing Asia Pty Ltd 2013 
The second important component of the economic integration is the transfer of factors, such as capital integration and interregional risk sharing that might play important roles in the convergence process of business cycles (Imbs 2004). The limited ability of provinces to borrow and lend hampers the transfer of resources that creates interregional risk sharing against economic shocks and, in that case, provinces are likely to have more correlated shifts in their business cycles (Imbs 2004).

Besides these forces, development of interprovincial networks, such as transportation and communication services, knowledge spillovers, and migration might contribute to the process of business cycle convergence.

\subsubsection{Pairwise business cycle correlations}

Besides correlations between provinces and the aggregate economy, it is also important to analyze the extent of bilateral business cycle correlations among provinces, as well as their evolution over time. Doing so might, in fact, be useful to help understand whether synchronization is rising within the country. To do so, I present a table of pairwise business cycle correlations among 67 provinces in Appendix I. In addition, Table 4 summarizes crosssectional averages of these correlations during four sub-periods. These equally long four subperiods are used because the time period (1975-2000) is not long enough to allow for more than four sub-periods.

I observe that bilateral correlations decrease until the mid-1980s, but tend to increase afterwards and hit the highest level during the most recent period, which is firmly consistent with my previous analysis.

\subsubsection{Evidence from the $2004-2008$ period}

It is well known that the Turkish economy has been going through a structural transformation since the severe crisis in 2001 (Akkoyun et al. 2012). For instance, its share in world exports has doubled, it has attracted a large amount of foreign investors, and the banking and financial sectors have been regulated (Akkoyun et al. 2012).

Under these circumstances, it is natural to ask whether rising synchronization of regional business cycles is still present. To understand this, I analyze the level of business cycle synchronization during the period of 2004-2008 compared to the period of 1975-2000. As mentioned in the introduction, no available regional data exists for the period of 2001-2004. TURKSTAT publishes GDP data for 67 provinces from the 1975-2000 period and gross value added data for 27 NUTS-2 regions from the 2004-2008 period. Therefore, these periods must be analyzed separately using different variables.

For both periods, NUTS-2 level regions are used because for the 2004-2008 period, regional data is only available at NUTS-2 level. In terms of the type of data, real gross value

Table 4. Average of pairwise correlations among provincial business cycles

\begin{tabular}{lrr}
\hline Period & BK & HP \\
\hline $1975-1980$ & 0.25 & 0.26 \\
$1981-1986$ & -0.01 & 0.05 \\
$1987-1993$ & 0.19 & 0.14 \\
$1994-2000$ & 0.41 & 0.38 \\
\hline
\end{tabular}

Note: Number of observations; 2,211 pairs of provinces. BK, Baxter-King; HP, Hodrick-Prescott. 
Table 5. Business cycle correlation between Nomenclature of Territorial Units for Statistics (NUTS)-2 regions and the aggregate economy

\begin{tabular}{|c|c|c|c|}
\hline \multicolumn{2}{|c|}{ Nuts-2 Regions } & \multirow{2}{*}{$\begin{array}{c}2004-2008 \\
0.90\end{array}$} & \multirow{2}{*}{$\begin{array}{c}1975-2000 \\
0.85\end{array}$} \\
\hline TR10 & İstanbul & & \\
\hline TR21 & Tekirdağ, Edirne, Kırklareli & 0.92 & 0.42 \\
\hline TR22 & Balıkesir, Çanakkale & -0.81 & 0.48 \\
\hline TR31 & İzmir & 0.99 & 0.46 \\
\hline TR32 & Aydın, Denizli, Muğla & 0.88 & 0.71 \\
\hline TR33 & Manisa, Afyon, Kütahya, Uşak & 0.88 & 0.76 \\
\hline TR41 & Bursa, Eskişehir, Bilecik & 0.99 & 0.88 \\
\hline TR42 & Kocaeli, Sakarya, Düzce, Bolu, Yalova & 0.91 & 0.52 \\
\hline TR51 & Ankara & 0.89 & 0.62 \\
\hline TR52 & Konya, Karaman & 0.56 & 0.73 \\
\hline TR61 & Antalya, Isparta, Burdur & 0.98 & 0.58 \\
\hline TR62 & Adana, Mersin & 0.98 & 0.43 \\
\hline TR63 & Hatay, Kahramanmaraş, Osmaniye & -0.76 & 0.37 \\
\hline TR71 & Kırıkkale, Aksaray, Niğgde, Nevşehir, Kırşehir & 0.42 & 0.65 \\
\hline TR72 & Kayseri, Sivas, Yozgat & 0.38 & 0.47 \\
\hline TR81 & Zonguldak, Karabük, Bartın & 0.95 & 0.48 \\
\hline TR82 & Kastamonu, Çankırı, Sinop & -0.61 & 0.48 \\
\hline TR83 & Samsun, Tokat, Çorum, Amasya & 0.45 & 0.74 \\
\hline TR90 & Trabzon, Ordu, Giresun, Rize, Artvin, Gümüşhane & 0.74 & 0.60 \\
\hline TRA1 & Erzurum, Erzincan, Bayburt & -0.26 & 0.58 \\
\hline TRA2 & Ağrı, Kars, Iğdır, Ardahan & 0.87 & 0.22 \\
\hline TRB1 & Malatya, Elazı̆̆, Bingöl, Tunceli & 0.36 & 0.57 \\
\hline TRB2 & Van, Muş, Bitlis, Hakkari & -0.12 & 0.61 \\
\hline TRC1 & Gaziantep, Adıyaman, Kilis & 0.91 & 0.66 \\
\hline $\mathrm{TRC} 2$ & Şanlıurfa, Diyarbakır & 0.99 & 0.66 \\
\hline \multirow[t]{2}{*}{ TRC3 } & Mardin, Batman, Şırnak, Siirt & 0.97 & 0.54 \\
\hline & Weighted mean: & 0.65 & 0.62 \\
\hline
\end{tabular}

added per capita has been employed for the recent period, while per capita real GDP has been used for the former. Regarding the business cycle measurement, I use the (logged) HP detrended series for both periods.

Table 5 summarizes pairwise business cycle correlations between NUTS-2 regions and the aggregate economy for both periods: 1975-2000 and 2004-2008. Cross-sectional weighted averages of these correlations point to a further increase in the synchronization, as it is 0.62 for 1975-2000 and 0.65 for 2004-2008. In other words, recently I observe more symmetric cycles within the country.

Finally, the results so far obtained have important implications for economic policies. Perhaps the most important lesson from this investigation is the fact that economic integration across provinces should indeed be promoted by strengthening the trade and financial linkages and removing all types of barriers that create cyclical asymmetries. Doing so might, in fact, help deal with the possible distortions in aggregate economic policies caused by asymmetric shocks.

\section{Conclusions}

The present paper has investigated business cycle synchronization in Turkey, as well as its recent tendencies and implied policies. 
The results can be summarized in two parts: first, the level of business cycle correlations between provinces and the aggregate economy is far below 1, which indicates the presence of considerable asymmetries in the economic shocks and business cycles across the provinces.

Second, from the 1990s onwards, cyclical asymmetries tend to decrease as higher and more homogenous business cycle correlations between provinces and the aggregate economy are observed. For the most recent time period (2004-2008), NUTS-2 level regions exhibit even higher correlations compared to the 1975-2000 period. These results, although they seem to provide evidence in favor of rising synchronization, show that convergence of cycles is rather slow, as regional asymmetries in the business cycles still exist.

Finally, from a policy point of view, the most important message of these results is the fact that interregional economic linkages should be further strengthened so as to avoid idiosyncratic cyclical movements across the provinces that might create sizable distortions in economic policies.

\section{Acknowledgement}

The author thanks the referees for their comments.

Submitted 9 December 2012.

Final version received 18 July 2013.

Send correspondence to Hasan Engin Duran: enginduran@iyte.edu.tr

\section{References}

Akkoyun, H.Ç., Mahmut, G. and Bahar, S.D. 2012. Business Cycle Synchronization of Turkey with Euro Area and the US: What Has Changed After 2001? Working Paper 12/15, Central Bank of the Republic of Turkey.

Alp, H., Baskaya, Y.S., Kilinç, M. and Yüksel, C. 2012. Stylized Facts for Business Cycles in Turkey, Working Paper 12/02, Central Bank of the Republic of Turkey.

Baxter, M. and King, R.G. 1999. Measuring Business Cycles: Approximate Bandpass Filters. The Review of Economics and Statistics 81(4), 575-593.

Baxter, M. and Kouparitsas, M.A. 2005. Determinants of Business Cycle Comovement: A Robust Analysis. Journal of Monetary Economics 52(1), 113-157.

Belke, A. and Heine, J. 2006. Specialisation Patterns and the Synchronicity of Regional Employment Cycles in Europe. International Economics and Economic Policy 3(2), 91-104.

Calderon, C., Alberto, C. and Ernesto, S. 2007. Trade intensity and business cycle synchronization: Are developing countries any different? Journal of International Economics 71(1), 2-21.

Carlino, G. and Defina, R. 1998. The Differential Regional Effects of Monetary Policy. The Review of Economics and Statistics 80(4), 572-587.

Carlino, G. and Sill, K. 2001. Regional Income Fluctuations: Common Trends and Common Cycles. The Review of Economics and Statistics 83(3), 446-456.

Clark, T. and van Wincoop, E. 2001. Borders and Business Cycles. Journal of International Economics $55(1), 59-85$.

Darvas, Z. and Szapáry, G. 2008. Business Cycle Synchronization in the Enlarged EU. Open Economies Review 19(1), 1-19.

Fatás, A. 1997. EMU: Countries or Regions? Lessons From the EMS Experience. European Economic Review 41(3-5), 743-751. 
Ferreira-Lopes, A. and Pina, M.A. 2011. Business Cycles, Core, and Periphery in Monetary Unions: Comparing Europe and North America. Open Economies Review 22(4), 565-592.

Ferreira-Lopes, A. and Sequeira, T. 2011. Business Cycles in Re-Unified Germany: Closer Together or Further Apart? Review of Urban and Regional Development Studies 23(2/3), 94-113.

Ferreira-Lopes, A. and Sequeira, T. 2012. Business Cycles Association in a Small Monetary Union: The Case of Switzerland. Spatial Economic Analysis 7(1), 9-30.

Filiztekin, A. 2004. Bölgesel Büyüme, Eş-hareketlilik ve Sektörel Yapı, Sabancı University.

Frankel, J.A. and Rose, A.K. 1998. The Endogeneity of the Optimum Currency Area Criteria. Economic Journal 108(449), 1009-1025.

Gezici, F. and Hewings, G.J.D. 2004. Regional Convergence and the Economic Performance of Peripheral Areas in Turkey. Review of Urban and Regional Development Studies 16(2), 113-132.

Hodrick, R. and Prescott, E.C. 1997. Postwar US Business Cycles: An Empirical Investigation. Journal of Money, Credit and Banking 29(1), 1-16.

Imbs, J. 2004. Trade, Finance, Specialization, and Synchronization. The Review of Economics and Statistics 86(3), 723-734.

Kalemli-Ozcan, S., Sorensen, B.E. and Yosha, O. 2001. Economic Integration, Industrial Specialization, and the Asymmetry of Macroeconomic Fluctuations. Journal of International Economics 55(1), 107137.

Karaca, O. 2004. Türkiye'de bölgeler arası gelir farklılıkları: yakınsama var mı? Türkiye Ekonomi Kurumu tartışma metni 2004/7.

Kasman, A. and Turgutlu, E. 2009. Testing Stochastic Convergence Among the Regions of Turkey. The International Journal of Emerging and Transition Economies 2(1), 81-98.

Krugman, P.R. 1991. Geography and Trade. Cambridge, MA, MIT Press.

Lee, M. 2005. Trade Integration and Business Cycle Comovement: Evidence from the US. The International Trade Journal 24(4), 361-388.

Montoya, L. and De Haan, J. 2008. Regional Business Cycle Synchronization in Europe? International Economics and Economic Policy 5(1), 123-137.

Mundell, R.A. 1961. A Theory of Optimum Currency Areas. American Economic Review 51(4), 657-665.

Owyang, M.T., Piger, J.M. and Wall, H.J. 2005. Business Cycle Phases in US States. The Review of Economics and Statistics 87(4), 604-616.

Selover, D., Jensen, R. and Kroll, J. 2005. Mode-Locking and Regional Business Cycle Synchronization. Journal of Regional Science 45(4), 703-745.

Weyerstrass, K., Aarle, B., Kappler, M. and Seymen, A. 2011. Business Cycle Synchronisation With(in) the Euro Area: In Search of a 'Euro Effect.' Open Economies Review 22(3), 427-446.

Yildirim, J., Ocal, N. and Ozyildirim, S. 2009. Income inequality and Economic Convergence in Turkey: A Spatial Effect Analysis. International Regional Science Review 32(2), 221-254. 
Appendix I. Pairwise business cycle correlations among provinces

\begin{tabular}{|c|c|c|c|c|c|c|c|c|c|c|c|c|c|}
\hline Provinces & Adana & Adiyaman & Afyon & Ağr 1 & Amasya & Ankara & Antalya & Artvin & Aydin & Balıkesir & Bilecik & Bingöl & Bitlis \\
\hline Adıyaman & 0.44 & & & & & & & & & & & & \\
\hline Afyon & 0.03 & 0.22 & & & & & & & & & & & \\
\hline Ağrı & 0.41 & 0.16 & -0.08 & & & & & & & & & & \\
\hline Amasya & 0.48 & 0.00 & 0.28 & -0.10 & & & & & & & & & \\
\hline Ankara & 0.31 & 0.72 & 0.06 & -0.06 & 0.06 & & & & & & & & \\
\hline Antalya & 0.23 & 0.26 & -0.43 & -0.09 & 0.00 & 0.54 & & & & & & & \\
\hline Artvin & 0.60 & 0.17 & -0.14 & -0.10 & 0.38 & 0.29 & 0.34 & & & & & & \\
\hline Aydın & 0.59 & 0.20 & 0.22 & 0.06 & 0.35 & 0.39 & 0.10 & 0.57 & & & & & \\
\hline Balıkesir & 0.31 & 0.16 & 0.17 & -0.26 & 0.34 & 0.31 & 0.11 & 0.57 & 0.78 & & & & \\
\hline Bilecik & 0.22 & 0.41 & 0.48 & 0.00 & -0.18 & 0.46 & 0.26 & 0.02 & 0.24 & 0.03 & & & \\
\hline Bingöl & 0.29 & 0.14 & 0.28 & 0.54 & 0.27 & 0.01 & -0.23 & -0.02 & 0.06 & 0.10 & -0.06 & & \\
\hline Bitlis & 0.70 & 0.30 & 0.38 & 0.31 & 0.66 & & & & & & 0.10 & 0.58 & \\
\hline Bolu & 0.47 & & -0.16 & 0.04 & & & & & & & 0.00 & & 0.28 \\
\hline Burdur & 0.03 & & 0.77 & -0.03 & & & & & & & & & 0.32 \\
\hline Bursa & 0.7 & & & & & & & & & & & & 0.66 \\
\hline Çan & 0.6 & & & -0 & & & & & & & & 01 & -0.17 \\
\hline Çankırı & -0 & & & - & & & & & & & & & 0.07 \\
\hline Çorum & 0.78 & & 0.17 & 0.15 & & & & 0.62 & 0.65 & & & 0.26 & 0.74 \\
\hline Denizli & 0.27 & & 0.31 & 0.32 & -0.04 & 0.41 & 0.50 & -0.09 & 0.14 & -0.02 & 0.62 & 0.13 & 0.04 \\
\hline Diya & 0.56 & & -0.04 & 0.01 & & 0.60 & 0.30 & 0.52 & 0.64 & 0.43 & 0.07 & -0.05 & 0.54 \\
\hline Edime & 0.26 & .02 & 0.59 & 0.28 & 0.44 & -0.37 & -0.48 & 0.07 & 0.13 & 0.14 & -0.09 & 0.44 & 0.37 \\
\hline Elazı̆ & 0.39 & & 0.34 & 0.23 & 0.20 & 0.45 & 0.11 & 0.23 & 0.50 & 0.42 & 0.39 & 0.29 & 0.36 \\
\hline Erzincan & 0.53 & 0.02 & 0.11 & 0.32 & 0.57 & -0.02 & -0.17 & 0.53 & 0.38 & 0.19 & -0.12 & 0.34 & 0.74 \\
\hline Erzurum & 0.52 & 0.41 & 0.22 & 0.49 & 0.00 & 0.26 & -0.31 & 0.19 & 0.44 & 0.19 & 0.21 & 0.31 & 0.52 \\
\hline Eskisehir & 0.31 & 50 & 0.55 & 0.14 & 0.23 & 0.35 & 0.01 & 0.39 & 0.42 & 0.37 & 0.36 & 0.12 & 0.30 \\
\hline Gaziantep & 0.65 & 40 & 0.03 & -0.06 & 0.50 & 0.64 & 0.36 & 0.58 & 0.56 & 0.30 & 0.25 & -0.04 & 0.59 \\
\hline Giresun & 0.48 & -0.03 & 0.30 & 0.32 & 0.53 & -0.18 & -0.28 & 0.32 & 0.31 & 0.21 & -0.01 & 0.39 & 0.72 \\
\hline Gümüşhan & 0.26 & 028 & 0.61 & 0.33 & 032 & 0.03 & -0.49 & 0.00 & 0.14 & 0.05 & 0.15 & 0.47 & 0.59 \\
\hline Hakkari & 0.20 & 4 & 0.17 & 0.07 & 0.27 & 0.49 & 0.01 & 0.16 & 0.22 & 0.29 & -0.07 & 0.37 & 0.45 \\
\hline Hatay & 0.48 & 0.52 & -0.34 & 0.04 & 013 & 0.77 & 0.83 & 0.36 & 0.33 & 0.16 & 0.29 & -0.17 & 0.12 \\
\hline Isparta & 0.33 & 037 & 0.51 & 0.38 & 0.39 & 0.07 & -0.04 & -0.07 & 0.02 & -0.12 & 0.30 & 0.39 & 0.51 \\
\hline İçel & -0.10 & 0.04 & 0.34 & -0.42 & 0.56 & 0.40 & 0.09 & 0.01 & 0.22 & 0.35 & 0.01 & 0.20 & 0.26 \\
\hline İstanbu & 0.75 & & 0.49 & 0.33 & 0.41 & 0.35 & -0.05 & 0.32 & 0.44 & 0.27 & 0.41 & 0.46 & 0.74 \\
\hline İzmir & 0.30 & 0.52 & 0.17 & 0.13 & 0.28 & 0.58 & 0.43 & 0.10 & 0.29 & 0.3 & 0.26 & 0.38 & 0.21 \\
\hline Kars & 0 & & & & & & & & & & & 9 & 0.2 \\
\hline & 0. & & & & & & & & & & & 6 & 0.6 \\
\hline & 0 & & & & & & & & & & & 1 & 0.6 \\
\hline Kurl & 0 & & & & & & & & & & & 3 & 0.50 \\
\hline & & & & & & & & & & & & & .5 \\
\hline & & & & & & & & & & & & & .4 \\
\hline Ko & & & & & & & & & & & & 6 & 0.47 \\
\hline Kütahya & -0.20 & & & & $-0.5 /$ & & 0.24 & -0.18 & -0.21 & -0.09 & 19 & 0.09 & -0.37 \\
\hline Malatya & 0.07 & -0.34 & 0.33 & -0.27 & 0.19 & -0.24 & -0.37 & 0.06 & 0.30 & 0.13 & 0.08 & -0.27 & 0.19 \\
\hline Manisa & 0.7 & .52 & 0.36 & 0.07 & 0.66 & 0.50 & 0.16 & 0.43 & 0.67 & 0.55 & 0.25 & 0.32 & 0.76 \\
\hline K. Maras & -0.09 & -0.01 & -0.10 & -0.38 & 0.12 & 0.23 & 0.40 & 0.10 & -0.20 & -0.08 & 0.15 & -0.02 & -0.17 \\
\hline Mardin & 0.16 & 0.64 & 0.55 & 0.00 & 0.21 & 0.61 & 0.02 & 0.15 & 0.26 & 0.34 & 0.33 & 0.42 & 0.43 \\
\hline Muğla & 0.33 & 0.40 & -0.21 & -0.14 & -0.01 & 0.52 & 0.82 & 0.36 & 0.31 & 0.40 & 0.32 & -0.11 & -0.08 \\
\hline Muş & 0.19 & 0.04 & 0.47 & 0.64 & 0.03 & -0.37 & -0.61 & -0.21 & 0.10 & -0.15 & 0.06 & 0.46 & 0.37 \\
\hline Nevşehir & 0.25 & 0.57 & 0.51 & 0.21 & -0.11 & 0.10 & -0.21 & 0.11 & 0.06 & 0.03 & 0.42 & 0.18 & 0.25 \\
\hline Nİ̆gde & 0.56 & 0.40 & 0.38 & 0.18 & 0.46 & -0.01 & -0.12 & 0.13 & 0.35 & 0.21 & 0.15 & 0.20 & 0.5 \\
\hline Ordu & 0.43 & -0.25 & 0.17 & 0.06 & 0.50 & -0.30 & -0.17 & 0.18 & 0.38 & 0.16 & 0.00 & 0.03 & 0.52 \\
\hline Rize & 0.3 & 0.44 & -0.22 & 0.53 & -0.43 & 0.20 & 0.17 & 0.13 & -0.04 & -0.24 & 0.26 & 0.02 & -0.06 \\
\hline Sakar & 0.4 & & 0.35 & -0.29 & 0. & 0.41 & 0.22 & 0.48 & 0.59 & 0.45 & 0.38 & 0.00 & 0.5 \\
\hline Samsu & 0.53 & & 0.30 & 0.25 & 0.39 & 0.43 & 0.41 & 0.26 & 0.26 & 0.20 & 0.50 & 0.37 & 0.4 \\
\hline Siirt & 0.0 & -0.06 & 0.25 & -0.16 & 0.45 & 0.2 & 0.09 & 0.18 & 0.12 & 0.14 & 0.08 & 0.21 & 0.50 \\
\hline Sino & 0.67 & 0.45 & 0.19 & 0.41 & 0.63 & 0.3 & 0.19 & 0.35 & 0.29 & 0.15 & 0.10 & 0.50 & 0.7 \\
\hline Siva & 0.65 & 0.71 & 0.17 & 0.39 & 0.25 & 0.51 & 0.17 & 0.43 & 0.36 & 0.08 & 0.25 & 0.21 & 0.47 \\
\hline Tekirdağ & 0.07 & 0.28 & 0.64 & -0.07 & 0.27 & 0.04 & 0.07 & -0.29 & -0.12 & 0.00 & 0.48 & 0.27 & 0.2 \\
\hline
\end{tabular}


Appindix I. Continued.

\begin{tabular}{|c|c|c|c|c|c|c|c|c|c|c|c|c|c|c|c|}
\hline Provinces & Adana & \multicolumn{2}{|c|}{ Adıyaman } & Afyon & A ğrı & Amasya & \multicolumn{2}{|c|}{ a Ankara } & Antalya & Artvin & Aydin & Balıkesir & Bilecik & ik Bingöl & \multirow{2}{*}{$\begin{array}{lr}1 & \text { Bitlis } \\
6 & 0.67\end{array}$} \\
\hline Tokat & 0.43 & 0. & & 0.35 & 0.03 & 0.78 & & .15 & 0.01 & 0.47 & 0.34 & 0.3 & -0 & 0.36 & \\
\hline Trabzon & 0.33 & 0. & & -0.21 & 0.45 & $5 \quad-0.11$ & & .47 & 0.57 & 0.01 & -0.18 & -0.2 & 0. & 0.19 & 0.12 \\
\hline Tunceli & -0.12 & 0 . & & 0.15 & 0.38 & 0.10 & -0 . & & -0.12 & -0.21 & -0.35 & -0.4 & -0 . & 0.23 & 0.21 \\
\hline Şanlıurfa & 0.25 & -0. & & 0.42 & 0.06 & 0.39 & -0 . & & -0.33 & 0.25 & 0.58 & 0.3 & 0. & 0.15 & 0.52 \\
\hline Uşak & 0.06 & 0. & 39 & 0.39 & 0.09 & $\begin{array}{ll}9 & -0.07\end{array}$ & 0. & .01 & 0.02 & 0.01 & -0.04 & -0.0 & 0. & 0.01 & $1-0.05$ \\
\hline Van & 0.56 & 0. & 50 & -0.11 & 0.27 & 0.32 & 0. & 65 & 0.48 & 0.46 & 0.37 & 0.3 & 0. & 0.39 & 0.44 \\
\hline Yozgat & 0.24 & 0. & & 0.20 & -0.02 & 0.33 & 0. & .27 & -0.31 & 0.28 & 0.48 & 0.3 & -0 . & 0.26 & 0.40 \\
\hline Zonguldak & 0.55 & 0. & 30 & 0.40 & 0.36 & 0.24 & -0 . & & -0.07 & 0.11 & 0.14 & -0.0 & 0. & 0.25 & 0.49 \\
\hline Provinces & Bolu & Burdur & Bursa & a C & e & in & $\mathrm{m}$ & $\mathrm{D}$ & izli Di & kir & dirne & $\overline{\text { Elazı } \breve{g} \mathrm{E}}$ & ncan & Erzurum $\mathrm{E}$ & Eskişehir \\
\hline Burdur & -0.30 & & & & & & & & & & & & & & \\
\hline Bursa & 0.46 & 0.13 & & & & & & & & & & & & & \\
\hline Çanakkale & -0.19 & 0.04 & 0.12 & & & & & & & & & & & & \\
\hline Çankin & -0.49 & 48 & 0.05 & & 0.43 & & & & & & & & & & \\
\hline Çorum & 0.56 & .16 & 0.72 & & 0.24 & -0.18 & & & & & & & & & \\
\hline Denizli & -0.11 & 0.39 & 0.32 & & 0.25 & 0.28 & 0.05 & & & & & & & & \\
\hline Diyarbak & 0.71 & -0.05 & 0.62 & & 0.32 & -0.26 & 0.77 & 0.04 & 04 & & & & & & \\
\hline Edirne & -0.21 & 0.48 & 0.31 & & 0.23 & 0.57 & 0.11 & 0.14 & 14 & -0.23 & & & & & \\
\hline Elazı $\breve{g}$ & -0.20 & 0.48 & 0.37 & & 0.05 & 0.28 & 0.42 & $0.4 \mathrm{C}$ & 49 & 0.21 & 0.19 & & & & \\
\hline Erzincan & 0.15 & 0.16 & 0.31 & & 0.38 & 0.00 & 0.59 & -0.15 & & 0.49 & 0.29 & 0.33 & & & \\
\hline Erzurum & 0.26 & 0.14 & 0.45 & & 0.15 & -0.14 & 0.62 & -0.04 & & 0.31 & 0.14 & 0.48 & 0.47 & & \\
\hline Eskişehir & -0.10 & 0.58 & 0.28 & & 0.09 & 0.47 & 0.43 & 0.46 & 46 & 0.21 & 0.45 & 0.73 & 0.43 & 0.43 & \\
\hline Gaziaiitep & 0.61 & .03 & 0.55 & & 0.31 & -0.23 & 0.86 & 0.10 & 10 & 0.89 & -0.22 & 0.23 & 0.48 & 0.32 & 0.26 \\
\hline Giresun & 0.20 & 30 & 0.43 & & 0.17 & 0.12 & 0.38 & $-0.0 \mathrm{~s}$ & & 0.33 & 0.46 & 0.22 & 0.78 & 0.35 & 0.28 \\
\hline Gümüşhane & -0.17 & 68 & 0.29 & & 0.22 & 0.35 & 0.37 & 0.08 & 08 & 0.09 & 0.51 & 0.51 & 0.57 & 0.64 & 0.62 \\
\hline Hakkari & 0.47 & 06 & 0.46 & & 0.22 & -0.08 & 0.50 & 0.04 & 04 & 0.54 & 0.09 & 0.04 & 0.29 & 0.20 & 0.22 \\
\hline Hatay & 0.47 & -0.27 & 0.47 & & 0.19 & -0.37 & 0.50 & 0.43 & 43 & 0.63 & -0.47 & 0.23 & 0.01 & 0.05 & 0.05 \\
\hline Isparta & -0.37 & 0.55 & 0.41 & & 0.08 & 0.55 & 0.21 & 0.62 & 62 & -0.02 & 0.56 & 0.55 & 0.34 & 0.16 & 0.60 \\
\hline İçel & -0.02 & 0.43 & 0.04 & & 0.34 & -0.02 & 0.33 & -0.01 & & 0.28 & -0.02 & 0.27 & 0.12 & -0.08 & 0.17 \\
\hline İstanbu & 0.22 & .48 & 0.75 & & 0.19 & 0.24 & 0.75 & 0.3 & 39 & 0.38 & 0.47 & 0.48 & 0.38 & 0.56 & 0.53 \\
\hline İzmir & -0.12 & .28 & 0.51 & & & 0.28 & 0.32 & 0.66 & 66 & 0.20 & 0.16 & 0.55 & -0.04 & -0.03 & 0.38 \\
\hline Kars & -0.13 & 19 & 0.19 & & 0 . & 0.08 & 0.18 & $0.0 \mathrm{~s}$ & 09 & -0.16 & 0.57 & 0.31 & 0.32 & 0.57 & 0.37 \\
\hline $\mathrm{Kas}$ & -0.06 & & & & 0 & 0.42 & .54 & 37 & 37 & & 0 . & 0.50 & 0.45 & 0.45 & 0.65 \\
\hline $\mathrm{Ka}$ & 0. & & & & 0. & -0.01 & 69 & 0.5 & 55 & & 0 & 0.53 & 0.38 & 7 & 0.57 \\
\hline $\mathrm{K}_{11}$ & 0 & & & & & 0 & 8 & -0.04 & & & & 5 & 7 & 3 & 0.13 \\
\hline Kur & 0. & & & & 0.01 & 0.16 & 0.55 & 0.24 & 24 & 0.45 & 0.33 & 0.19 & 0.48 & 0.30 & 0.24 \\
\hline $\mathrm{Kor}$ & 0. & 6 & 0.50 & & 0.17 & -0.03 & 0.37 & 0.2 & 29 & 0.37 & 0.31 & -0.08 & 0.09 & -0.04 & 0.06 \\
\hline $\mathrm{K}_{0}$ & 0 . & 30 & 0 & & 0.02 & 0.19 & 0.57 & 0.62 & 62 & 0.66 & 0.10 & 0.48 & 0.36 & 0.32 & 0.53 \\
\hline Küt & -0.38 & 0.18 & -0.16 & & 0.20 & 0.11 & -0.25 & $0.4 \mathrm{c}$ & 49 & -0.45 & -0.04 & 0.28 & -0.45 & 0.05 & 0.23 \\
\hline Malatya & 0.40 & -0.02 & 0.15 & & 0.05 & 0.01 & 0.08 & -0.30 & & 0.21 & 0.20 & -0.35 & 0.11 & -0.02 & -0.16 \\
\hline Manisa & 0.42 & 0.37 & 0.78 & & 0.07 & 0.13 & 0.85 & 0.25 & 29 & 0.65 & 0.27 & 0.53 & 0.40 & 0.44 & 0.44 \\
\hline K. Maras & -0.07 & -0.17 & -0.17 & & -0.11 & -0.05 & -0.14 & 0.06 & 06 & -0.18 & -0.20 & -0.07 & -0.28 & -0.47 & -0.25 \\
\hline Mardin & 0.13 & 0.50 & 0.35 & & -0.23 & 0.21 & 0.44 & 0.34 & 34 & 0.40 & 0.14 & 0.44 & 0.27 & 0.31 & 0.57 \\
\hline Muğla & 0.27 & -0.11 & 0.30 & & 0.26 & -0.07 & 0.16 & 0.53 & 53 & 0.30 & -0.25 & 0.22 & -0.24 & -0.24 & 0.06 \\
\hline Muş & -0.26 & 0.38 & 0.19 & & 0.20 & 0.38 & 0.00 & 0.21 & 21 & -0.16 & 0.61 & 0.33 & 0.36 & 0.41 & 0.36 \\
\hline Nevşehi & -0.21 & 0.28 & 0.27 & & 0.29 & 0.57 & 0.16 & 0.41 & 41 & -0.04 & 0.43 & 0.28 & 0.14 & 0.35 & 0.58 \\
\hline Niğgde & 0.02 & .31 & & & 0.38 & 0.60 & 0.33 & 0.3 & 39 & 0.33 & 0.42 & 0.38 & 0.43 & 0.23 & 0.38 \\
\hline Ordu & 0.25 & 0.11 & 0.31 & & 0.12 & 0.11 & 0.21 & -0.06 & & 0.33 & 0.25 & 0.07 & 0.52 & 0.06 & -0.04 \\
\hline Rize & 0.03 & -0.24 & 0.15 & & -0.02 & -0.05 & 0.04 & 0.30 & 30 & 0.04 & -0.15 & 0.15 & 0.09 & 0.40 & 0.16 \\
\hline Sakar & 0.60 & 0.22 & 0. & & -0.09 & -0.05 & 0.59 & 0.13 & 13 & 0.6 & 0.01 & 0.09 & 0.32 & 0.01 & 0.16 \\
\hline Sams & 0.02 & 0.57 & 0.50 & & -0.02 & 0.05 & 0.47 & 0.58 & 58 & 0.21 & 0.24 & 0.64 & 0.23 & 0.21 & 0.45 \\
\hline Siirt & 0.40 & 0.21 & 0.25 & & -0.47 & -0.25 & 0.39 & -0.10 & & 0.53 & -0.02 & -0.19 & 0.40 & -0.06 & -0.01 \\
\hline Sinc & & 0.32 & & & -0.20 & 0.14 & 0.68 & 0.37 & 37 & 0.57 & 0.30 & 0.46 & 0.70 & 0.34 & 0.46 \\
\hline Siva & & 0.13 & 0.46 & & -0.27 & 0.10 & 0.61 & 0.40 & 40 & 0.47 & 0.18 & 0.51 & 0.51 & 0.57 & 0.63 \\
\hline Tekirdağ & -0.41 & 0.69 & 0.20 & & 0.33 & 0.57 & -0.08 & 0.62 & - & -0.27 & 0.43 & 0.35 & -0.18 & -0.15 & 0.28 \\
\hline
\end{tabular}


Appindix I. Continued.

\begin{tabular}{|c|c|c|c|c|c|c|c|c|c|c|c|c|c|c|}
\hline Provinces & Bolu $\mathrm{F}$ & Burdur $\mathrm{E}$ & Bursa Çe & Çanakkale & Çankin & in Çoru & um Den & nizli Diya & iyarbakir & Edirne & Elazı̆̆ $\mathrm{I}$ & Erzincan & Erzurum $\mathrm{E}$ & Eskişe \\
\hline Tokat & 0.20 & 0.52 & 0.38 & -0.37 & 0.09 & & 62 & 0.01 & 0.53 & 0.40 & 0.27 & 0.72 & 0.21 & 0.44 \\
\hline Trabzon & 0.01 & -0.01 & 0.34 & -0.16 & -0.18 & & 15 & 0.55 & 0.09 & -0.21 & 0.31 & 0.03 & 0.17 & 0.13 \\
\hline Tunceli & -0.47 & 0.33 & -0.02 & -0.42 & 0.28 & $8-0.0$ & .09 & 0.23 & -0.09 & 0.18 & 0.34 & 0.41 & 0.09 & 0.40 \\
\hline Şanlıurfa & 0.31 & 0.38 & 0.22 & -0.23 & -0.13 & & $\begin{array}{ll}51-0 .\end{array}$ & 0.17 & 0.42 & 0.30 & 0.19 & 0.53 & 0.39 & 0.35 \\
\hline Uşak & -0.38 & 0.36 & 0.08 & 0.40 & 0.78 & $\begin{array}{ll}8 & -0.2\end{array}$ & 20 & 0.61 & -0.19 & 0.35 & 0.31 & -0.05 & -0.12 & 0.52 \\
\hline Van & 0.53 & -0.04 & 0.55 & -0.38 & -0.34 & & 64 & 0.19 & 0.58 & -0.10 & 0.26 & 0.28 & 0.35 & 0.18 \\
\hline Yozgat & 0.36 & 0.21 & 0.25 & -0.29 & -0.10 & & 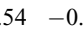 & 0.32 & 0.42 & 0.10 & 0.30 & 0.42 & 0.47 & 0.23 \\
\hline Zonguldak & -0.10 & 0.42 & 0.45 & 0.37 & 0.55 & & 27 & 0.48 & 0.03 & 0.51 & 0.34 & 0.29 & 0.29 & 0.44 \\
\hline Provinces & \multicolumn{5}{|c|}{ Gaziantep Giresun Gümüşhane Hakkari } & Hatay & $\operatorname{arta}$ & İçel İst & İstanbul & İzmir & Kars K & \multicolumn{3}{|c|}{ Kastamonu Kayseri Kırklareli } \\
\hline Giresun & 0.21 & & & & & & & & & & & & & \\
\hline Gümüşhane & 0.10 & 0.59 & & & & & & & & & & & & \\
\hline Hakkari & 0.40 & 0.22 & 22 & 0.22 & & & & & & & & & & \\
\hline Hatay & $0.6 ?$ & -0.15 & & -0.33 & 0.24 & & & & & & & & & \\
\hline Isparta & 0.10 & 0.31 & 31 & 0.52 & 0.12 & 0.02 & & & & & & & & \\
\hline İçel & 0.33 & -0.04 & & 0.16 & 0.40 & 0.16 & 0.11 & & & & & & & \\
\hline İstanbu & 0.54 & 0.37 & 37 & 0.56 & 0.34 & 0.18 & 0.59 & 0.08 & & & & & & \\
\hline İzmir & 0.24 & -0.13 & & 0.04 & 0.36 & 0.47 & 0.55 & 0.38 & 0.46 & & & & & \\
\hline Kars & -0.12 & 0.37 & 37 & 0.48 & -0.21 & -0.28 & 0.28 & -0.27 & 0.35 & -0.07 & & & & \\
\hline Kastamonu & 0.42 & 0.47 & 47 & 0.74 & 0.25 & -0.02 & 0.71 & 0.22 & 0.81 & 0.31 & 0.26 & & & \\
\hline Kayseri & 0.53 & 0.30 & 30 & 0.54 & 0.59 & 0.42 & 0.54 & 0.16 & 0.79 & 0.56 & 0.24 & 0.67 & & \\
\hline Kirklareli & 0.07 & 0.44 & 44 & 0.30 & -0.06 & -0.32 & 0.23 & -0.08 & 0.55 & -0.05 & 0.46 & 0.42 & 0.13 & \\
\hline Kırşehir & 0.57 & 0.44 & 44 & 0.35 & 0.03 & 0.19 & 0.33 & 0.01 & 0.62 & 0.18 & 0.33 & 0.46 & 0.36 & 0.40 \\
\hline Kocaeli & 0.39 & 0.26 & 26 & 0.03 & 0.33 & 0.28 & 0.29 & 0.27 & 0.37 & 0.28 & 0.14 & 0.32 & 0.28 & 0.23 \\
\hline Konya & 0.60 & 0.34 & 34 & 0.35 & 0.44 & 0.57 & 0.40 & 0.09 & 0.58 & 0.48 & 0.05 & 0.46 & 0.74 & -0.04 \\
\hline Kütahya & -0.37 & -0.38 & & 0.04 & -0.16 & 0.08 & 0.09 & -0.14 & 0.01 & 0.31 & 0.09 & 0.08 & 0.17 & -0.09 \\
\hline Malatya & 0.14 & 0.38 & -0 & -0.03 & -0.02 & -0.22 & -0.18 & -0.10 & 0.05 & -0.38 & 0.08 & 0.08 & -0.29 & 0.29 \\
\hline Manisa & 0.72 & 0.36 & & 0.35 & 0.44 & 0.44 & 0.43 & 0.42 & 0.81 & 0.53 & 0.12 & 0.60 & 0.67 & 0.36 \\
\hline K. Maras & -0.02 & -0.16 & & 0.39 & -0.19 & 0.26 & -0.11 & $0.21-$ & -0.23 & 0.20 & -0.24 & -0.14 & -0.27 & 0.13 \\
\hline Mardin & 0 & 0.26 & & 0.56 & 0.72 & 0.17 & 0.31 & 0.45 & 0.45 & 0.46 & 0.00 & 0.55 & 0.69 & -0.01 \\
\hline Muğla & 0.26 & -0.16 & & 0.46 & 0.09 & 0.73 & 0.00 & 0.02 & 0.10 & 0.53 & -0.30 & -0.10 & 0.22 & -0.12 \\
\hline Muş & -0.18 & 0.41 & & 0.62 & -0.05 & -0.52 & 0.54 & -0.28 & 0.42 & -0.01 & 0.64 & 0.42 & 0.29 & 0.40 \\
\hline Nevşehir & & 0.10 & & 0.45 & 0.17 & -0.11 & 0.53 & -0.29 & 0 . & 0.24 & 0.39 & 0.58 & 0.46 & 0.20 \\
\hline Niğde & 2 & 0.44 & & 0.41 & 0.20 & 0.06 & 0.60 & -0.02 & 0.58 & 0.35 & 0.14 & 0.54 & 0.38 & 0.24 \\
\hline Ordu & 6 & 0.72 & & 0.17 & -0.11 & -0.06 & 0.15 & -0.05 & 0.20 & -0.17 & 0.11 & 0.23 & -0.09 & 0.39 \\
\hline Rize & 0.03 & 0.06 & & 0.17 & -0.14 & 0.25 & 0.03 & -0.66 & 0.12 & -0.01 & 0.35 & 0.05 & 0.32 & -0.14 \\
\hline Sakarya & 0.73 & 0.40 & & 0.04 & 0.36 & 0.36 & 0.02 & 0.39 & 0.42 & 0.16 & -0.12 & 0.41 & 0.28 & 0.33 \\
\hline Samsu & 0.33 & 0.34 & & 0.37 & 0.03 & 0.39 & 0.49 & 0.26 & 0.60 & 0.51 & 0.18 & 0.58 & 0.61 & 0.36 \\
\hline Siirt & 0.46 & 0.49 & & 0.14 & 0.57 & 0.19 & 0.01 & 0.46 & 0.14 & $0.00-$ & -0.24 & 0.31 & 0.28 & 0.01 \\
\hline Sinop & 0.59 & 0.56 & & 0.51 & 0.48 & 0.41 & 0.64 & 0.25 & 0.66 & 0.53 & 0.13 & 0.62 & 0.75 & 0.11 \\
\hline Sivas & 0.52 & 0.26 & & 0.51 & 0.36 & 0.43 & 0.41 & 0.02 & 0.55 & 0.33 & 0.35 & 0.44 & 0.69 & 0.07 \\
\hline Tekirdăg & -0.15 & 0.12 & & 0.30 & -0.07 & -0.04 & 0.63 & 0.26 & 0.37 & 0.45 & 0.05 & 0.55 & 0.25 & 0.26 \\
\hline Tokat & 0.51 & 0.64 & & 0.55 & 0.43 & 0.10 & 0.31 & 0.49 & 0.45 & 0.14 & 0.10 & 0.52 & 0.45 & 0.23 \\
\hline Trabzon & 0.13 & 0.11 & & 0.11 & 0.06 & 0.59 & 0.31 & -0.18 & 0.20 & 0.37 & 0.01 & 0.20 & 0.54 & -0.15 \\
\hline Tunce & -0.10 & 0.28 & & 0.54 & 0.01 & -0.14 & 0.62 & 0.02 & 0.05 & 0.14 & 0.11 & 0.35 & 0.27 & -0.20 \\
\hline Şanlıur & & 0.40 & & 0.37 & 0.24 & -0.16 & 0.16 & 0.32 & 0.38 & -0.12 & 0.28 & 0.36 & 0.25 & 0.31 \\
\hline Uşak & -0.14 & 0.05 & & 0.25 & -0.09 & -0.13 & 0.56 & -0.32 & 0.29 & 0.37 & 0.16 & 0.40 & 0.22 & 0.09 \\
\hline Van & 0.53 & 0.25 & & 0.10 & 0.51 & 0.67 & 0.04 & 0.25 & 0.34 & 0.38 & 0.08 & 0.15 & 0.63 & -0.03 \\
\hline Yozgat & 0.38 & 0.33 & & 0.47 & 0.31 & -0.08 & -0.14 & 0.35 & 0.32 & 0.03 & 0.12 & 0.23 & 0.21 & 0.23 \\
\hline Zonguldak & 0.18 & 0.34 & & 0.45 & -0.11 & -0.03 & 0.71 & -0.31 & 0.71 & 0.28 & 0.33 & 0.68 & 0.43 & 0.41 \\
\hline Provinces & Kırşehir & Kocaeli & $\mathrm{i} \mathrm{K}$ & $\mathrm{a} \mathrm{K}$ & $\mathrm{M}$ & $\mathrm{y} \mathrm{M}$ & Manisa & K. Maraş & aş $\mathrm{Ma}$ & $\operatorname{lin} \mathrm{N}$ & $\mathrm{a}$ & Nevşe & ehir Niğde & e Ordu \\
\hline & & & & & & & & & & & & & & \\
\hline Konya & & & & & & & & & & & & & & \\
\hline Kütahya & -0.34 & -0.14 & & & & & & & & & & & & \\
\hline Malatya & 0.32 & 0.57 & 0.10 & & & & & & & & & & & \\
\hline Manisa & 0.58 & 0.43 & 0.66 & -0.24 & & .09 & & & & & & & & \\
\hline
\end{tabular}


Appindix I. Continued.

\begin{tabular}{|c|c|c|c|c|c|c|c|c|c|c|c|c|c|c|}
\hline Provinces & Kırşehir & r Kocael & li Konya & Kütal & & Malatya & Manisa & K. Maraş & ş Mardin & Muğla & a Muş & Nevşehir & ir Niğgde & le Ordu \\
\hline K. Maras & -0.07 & 0.24 & -0.19 & 0.2 & & -0.03 & -0.10 & & & & & & & \\
\hline Mardin & 0.11 & 0.27 & 0.61 & 0.2 & & -0.12 & 0.45 & -0.08 & & & & & & \\
\hline Muğla & -0.01 & 0.17 & 0.47 & 0.3 & & -0.15 & 0.33 & 0.36 & 0.14 & & & & & \\
\hline Muş & 0.35 & 0.00 & 0.13 & -0.0 & & 0.04 & 0.09 & -0.55 & 0.10 & -0.51 & & & & \\
\hline Nevşehir & 0.17 & 0.10 & 0.38 & 0.4 & & -0.02 & 0.20 & -0.34 & 0.45 & -0.01 & 0.47 & & & \\
\hline NIĬgde & 0.64 & 0.25 & 0.64 & -0.1 & & 0.17 & 0.57 & -0.33 & 0.31 & 0.09 & 0.49 & 0.55 & & \\
\hline Ordu & 0.61 & 0.36 & 0.23 & -0.5 & & 0.64 & 0.32 & -0.04 & -0.13 & -0.04 & 0.28 & -0.12 & 0.56 & \\
\hline Rize & 0.18 & -0.19 & 0.38 & 0.4 & & -0.25 & -0.17 & -0.12 & 0.10 & 0.11 & 0.21 & 0.46 & 0.12 & $2-0.12$ \\
\hline Sakarya & 0.57 & 0.65 & 0.47 & -0.3 & & 0.53 & 0.62 & 0.23 & 0.37 & 0.31 & $1-0.18$ & -0.04 & 0.33 & 0.54 \\
\hline Samsun & 0.36 & 0.25 & 0.52 & 0.2 & & -0.24 & 0.56 & 0.25 & 0.35 & 0.39 & 0.10 & 0.08 & 0.21 & 0.18 \\
\hline Siirt & 0.13 & 0.56 & 0.22 & -0.2 & & 0.38 & 0.28 & 0.11 & 0.46 & 0.06 & $5-0.23$ & -0.12 & 0.02 & 0.31 \\
\hline Sinop & 0.56 & 0.34 & 0.70 & -0.1 & & -0.15 & 0.65 & -0.14 & 0.52 & 0.15 & 0.25 & 0.32 & 0.61 & 0.32 \\
\hline Sivas & 0.51 & 0.17 & 0.77 & 0.1 & & -0.24 & 0.50 & -0.20 & 0.55 & 0.12 & 0.25 & 0.52 & 0.48 & 0.00 \\
\hline Tekirdağ & 0.13 & 0.32 & 0.26 & 0.3 & & -0.07 & 0.30 & 0.22 & 0.32 & 0.23 & 0.18 & 0.35 & 0.41 & 0.11 \\
\hline Tokat & 0.45 & 0.30 & 0.50 & -0.3 & & 0.08 & 0.55 & -0.16 & 0.50 & -0.04 & 0.12 & 0.06 & 0.36 & 0.38 \\
\hline Trabzon & 0.02 & 0.02 & 0.44 & 0.4 & & -0.49 & 0.11 & 0.26 & 0.22 & 0.43 & $3-0.11$ & 0.12 & 0.00 & $0 \quad-0.17$ \\
\hline Tunceli & 0.03 & -0.12 & 0.13 & 0.0 & & -0.33 & -0.13 & -0.13 & 0.23 & -0.34 & 0.43 & 0.19 & 0.16 & $6-0.01$ \\
\hline Sanliur & 0.33 & 0.30 & 0.11 & -0.4 & & 0.43 & 0.47 & -0.48 & 0.16 & -0.25 & 0.33 & -0.02 & 0.18 & 0.37 \\
\hline Uşak & 0.22 & 0.01 & 0.38 & 0.3 & & -0.09 & 0.02 & -0.03 & 0.28 & 0.15 & 0.42 & 0.70 & 0.53 & 0.00 \\
\hline Van & 0.20 & 0.28 & 0.57 & 0.0 & & -0.25 & 0.56 & 0.18 & 0.45 & 0.49 & -0.29 & -0.07 & -0.01 & $1-0.09$ \\
\hline Yozgat & 0.41 & 0.10 & 0.18 & -0.2 & & 0.23 & 0.37 & -0.06 & 0.38 & -0.27 & 0.13 & -0.16 & 0.07 & 0.26 \\
\hline Zonguldak & 0.63 & 0.21 & 0.46 & 0.0 & & 0.12 & 0.44 & -0.23 & 0.11 & 0.06 & 0.56 & 0.62 & 0.73 & 0.39 \\
\hline Provinces & Rize $\mathrm{S}$ & Sakarya & Samsun & Siirt & Sinop & p Sivas & Tekirdağ & Tokat $\mathrm{T}$ & Trabzon & Tunceli & Şanlıurfa & Uşak & Van & Yozgat \\
\hline Sakarya & -0.24 & & & & & & & & & & & & & \\
\hline Samsun & 0.11 & 0.36 & & & & & & & & & & & & \\
\hline Siirt & -0.29 & 0.65 & 0.18 & & & & & & & & & & & \\
\hline Sinop & 0.19 & 0.36 & 0.58 & 0.43 & & & & & & & & & & \\
\hline Sivas & 0.55 & 0.18 & 0.38 & 0.01 & 0.67 & & & & & & & & & \\
\hline Tekirdağ & -0.15 & 0.14 & 0.58 & 0.07 & 0.25 & $5 \quad 0.05$ & & & & & & & & \\
\hline Tokat & -0.19 & 0.51 & 0.49 & 0.63 & 0.73 & $3 \quad 0.44$ & 0.19 & & & & & & & \\
\hline Trabzon & 0.60 & -0.09 & 0.59 & 0.04 & 0.44 & $4 \quad 0.43$ & 0.27 & 0.02 & & & & & & \\
\hline Tunceli & 0.23 & -0.33 & 0.20 & 0.04 & 0.45 & $5 \quad 0.30$ & 0.16 & 0.25 & 0.36 & & & & & \\
\hline Şanlıurfa & -0.43 & 0.41 & 0.05 & 0.37 & 0.22 & $2 \quad 0.09$ & -0.15 & 0.50 & -0.48 & 0.00 & & & & \\
\hline Uşak & 0.38 & -0.03 & 0.17 & -0.29 & 0.18 & 30.29 & 0.47 & -0.08 & 0.17 & 0.35 & -0.26 & & & \\
\hline Van & 0.20 & 0.34 & 0.46 & 0.41 & 0.53 & $3 \quad 0.49$ & -0.04 & 0.41 & 0.53 & -0.05 & 0.07 & -0.25 & & \\
\hline Yozgat & -0.09 & 0.38 & 0.16 & 0.20 & 0.24 & $4 \quad 0.26$ & -0.28 & 0.42 & -0.25 & 0.02 & 0.44 & -0.22 & 0.21 & \\
\hline Zonguldak & 0.29 & 0.14 & 0.38 & -0.13 & 0.50 & 0.39 & 0.46 & 0.20 & 0.16 & 0.28 & 0.17 & $0.61-$ & -0.04 & -0.01 \\
\hline
\end{tabular}

